\title{
DE VÍTIMAS A INDICIADOS, UM PROCESSO DE PONTA-CABEÇA: SURUÍ AIKEWÁRA VERSUS DIVINO ETERNO - LAUDO ANTRÓPOLÓGICO
}

JANE FELIPE BELTRÃ̄O ${ }^{1}$

$U F P A$

LUIZA DE NAZARÉ MASTOP-LIMA ${ }^{2}$

$U F P A$

HÉLIO LUIZ FONSECA MOREIRA ${ }^{3}$

$U F P A$

RESUMO: Após 30 anos de incômoda convivência com a estrada estadual, antes conhecida como $O P-2$, posteriormente $P A-253$ e hoje $B R-153$, aberta pelo exército brasileiro à época da Guerrilha do Araguaia, os Suruí Aikewára conseguiram com auxilio da Procuradoria da República estabelecer, mediante laudo antropológico e estudos de impacto ambiental, "acordo" com o Governo do Estado do Pará para mitigar o impacto da rodovia. Entretanto, as cláusulas da negociação não vêm sendo cumpridas, fato que gera descontentamento entre os indios. Os Suruí, premidos pelos problemas causados pela rodovia, não possuem outro recurso que "entupedinir" (obstruir) a rodovia, vez por outra, para chamar atenção das autoridades. À última manifestação de descontentamento em março de 2003, provocada pela descoberta de mais um cadáver "despejado" em suas terras, o caminhoneiro de nome Divino Eterno ultrapassou os obstáculos e atirou o veículo sobre os jovens Suruí que guarneciam a obstrução da rodovia. Na defesa de seu território e na ausência de autoridades constituidas, os guerreiros retiveram o veículo, o motorista e a mulher que o acompanhava. Depois de algum tempo, a "liberação" dos retidos e do veículo pelos representantes do órgão tutelar, à revelia dos Suruí, possibilitou que, liberado, Divino Eterno oferecesse queixa, na delegacia de São Geraldo do Araguaia, contra três Suruí Aikewára. A ação dos representantes da FUNAI gerou um processo de ponta-cabeça, posto que de vítimas (agredidos) os Surui passaram a indiciados (agressores).

\footnotetext{
${ }^{1}$ Antropóloga e historiadora, docente junto ao Instituto de Filosofia e Ciências Humanas (IFCH) da Universidade Federal do Pará (UFPA). Pesquisadora do CNPq. Coordenadora do grupo de estudo para elaboração do laudo, constituído a partir da Instituição, integrado pela antropóloga Luiza de Nazaré MastopLima, e pelo advogado Hélio Luiz Fonseca Moreira, em atendimento à solicitação da Dr ${ }^{\mathrm{a}}$ Ela Wiecko Volkemer de Castilho, Subprocuradora Geral da República e Coordenadora da $6{ }^{a}$ Câmara de Coordenação e Revisão do Ministério Público Federal (MPF) e Dr ${ }^{a}$ Eloísa Helena Machado Procuradora da República em Marabá, referendado pela Associação Brasileira de Antropologia (ABA). E-mail: jane@ufufa.br .

${ }^{2}$ Antropóloga, docente junto à Faculdade de Agronomia do Campus Universitário de Marabá da UFPA. Email: luizaamastop@ufpa.br.

${ }^{3}$ Advogado, sociólogo, professor junto ao Instituto de Ciências Jurídicas (ICJ)/UFPA.
}

Espaço Ameríndio, Porto Alegre, v. 2, n. 2, p. 194-258, jul./dez. 2008. 
BELTRÃO, MASTOP-LIMA e MOREIRA - De vítimas a indiciados ...

PALAVRAS-CHAVE: Suruí Aikewára; Etnologia indígena; conflitos interétnicos; laudo antropológico.

\begin{abstract}
Discussion of conflicts arising from infra-structure projects in state and federal roads which cross Indian Territory Sororó (AIS), land of the Suruí Aikewára, in southeast Pará, Brazil. After 30 years of inconvenience caused by the OP-2 later PA-253 and currently BR-153 opened by the Brazilian Army at the time of conflict with those fighting in the Araguaia Guerrilla, the Surui Aikewarra, with the aid of Federal Attorney Office, anthropological expert opinion and environmental impact study (EIA), to settle the matter with the Pará State Government to mitigate losses due to the road construction. Some of the items of the agreement, though, have not been complied with despite of the Federal Attorney Office mediation - a fact of great dislike to the Indian population who have been left with no other option, but to protest by closing the road once and again, in attempts to call attention of the State authorities. During the latest of the protests in March 2003 - provoked by the finding of a corpse in Indian Territory-truck driver, Divino Eterno, ran into young Surui who obstructed the road and protected the entrance to their village. In defense of those threatened, the Indians in the scene, detained the driver and his female companion at the time. Much to the dislike of the Indians and against their will - especially that of the Indian mothers who had their children threatened by the driver action -, the detainees were released by Funai (Indian National Foundation) representatives. Once free, Divino Eterno registered a complaint at São Geraldo Police Station against three Surui Aikewará. The action of Funai representatives has generated an upside down trial by reversing the position of the Indians from victims to the status of defendants.
\end{abstract}

KEYWORDS: Suruí Aikewára; Indian Ethnology; interethnical conflicts; anthropological arbitral report.

\title{
A propósito de laudos antropológicos
}

Laudos antropológicos são sempre resultado de ação política, pois o exercício da Antropologia volta-se à demonstração da diversidade cultural na tentativa de compreendê-la e de informar os demais sobre o fato. Especialmente, porque o homem não realiza sua natureza ímpar numa humanidade abstrata, como ensina Lévi-Strauss (1970), sobretudo, quando o mundo é marcado pela intolerância que toma a diferença como desigualdade. Ao tomar os povos indígenas como desiguais, os demais (brasileiros) desconsideram os membros de qualquer uma das 220 etnias existentes no Brasil.

Espaço Ameríndio, Porto Alegre, v. 2, n. 2, p. 194-258, jul./dez. 2008. 
BELTRÃO, MASTOP-LIMA e MOREIRA - De vítimas a indiciados ...

Em cenários conflituosos, como o sul do Pará, a intolerância se agrava. Desconsiderados, os povos indígenas buscam seus direitos e, freqüentemente, os antropólogos - acionados pelo Ministério Público Federal - são ouvidos para dirimir dúvidas e informar às autoridades sobre as condições do conflito e o ponto de vista dos indígenas envolvidos, na tentativa de ter, no processo, os direitos diferenciados assegurados a partir do texto constitucional.

\begin{abstract}
A maior parte das pesquisas em Ciências Sociais [particularmente na Antropologia] envolve contatos diretos, íntimos e mais ou menos perturbadores com os detalhes imediatos da vida contemporânea, contatos de um tipo que dificilmente pode deixar de afetar a sensibilidade das pessoas que os realizam (GEERTZ, 2001, p. 31).
\end{abstract}

Assim sendo, como quer Geertz (1998), fazer laudos é tarefa política que exige fina sensibilidade.

Aqui, não se fala em abstrato, referimo-nos à postura que deve pautar o dia a dia, secundada ou não por uma discussão mais intensa e densa. Postura que conduz a interrogações impertinentes: como agir diante das demandas oriundas de grupos sociais étnica e politicamente diferenciados? Como buscar um norte em meio a grupos orientados por lastro cultural diverso, que indica passado compartilhado com sociedades diferentes da ocidental? Como seguir caminho considerando lealdades e direitos coletivos em favor de demandas que tentam diminuir relações assimétricas, estabelecidas desde os tempos coloniais? Em resumo, como apresentar a diversidade dos Povos Indígenas a sociedades que Ihes são adversas?

Fala-se, freqüentemente, em diferença, marcador que consideramos fundamental e emblemático à Antropologia, mas os universais e as semelhanças estão aí para serem tratados. Entretanto, na maioria das vezes, não foram tratados, na verdade foram maltratados, ou melhor, ignorados e esquecidos. Em grande parte das demandas nas quais os antropólogos são convidados/chamados a atuar, os povos possuem enorme poder de expressão oral, eloqüência nem sempre presente nos 
BELTRÃO, MASTOP-LIMA e MOREIRA - De vítimas a indiciados ...

laudos, pela impossibilidade de transcrição, às peças escritas e fundamentadas que, como peritos, somos obrigados a produzir.

Os Povos Indígenas possuem a capacidade de expressão oral a que nos referimos antes, mas as ferramentas de trabalho do antropólogo não captam $50 \%$ do que nos foi/é dito, sendo otimistas! O fato transforma laudos em peças, não muito expressivas, se considerarmos a gravidade das dificuldades e, sobretudo, dos conflitos referidos pelos demandantes dos serviços antropológicos. Por outro lado, os Povos Indígenas ao se expressarem com eloqüência nem sempre são compreendidos pelas autoridades, pois usam epistemologia própria (FERNÁNDEZ, 2002; MOREIRA, 2005). Mas, as autoridades, mesmo sem compreender integralmente o dito, terminam por decidir suas vidas, desde a oferta de uma simples oficina até a solução de conflitos de terra. As questões e os desafios enfrentados pelos antropólogos não passam, unicamente, pela diferença, mas, especialmente, pelo entendimento da diversidade como direito à diferença e não como sinônimo de desigualdade. Temos obrigação de buscar instrumentos eficientes de transcrição da eloqüência dos povos com quem dialogamos para evitar que os equívocos se perpetuem. Urge compreender a epistemologia indígena e torná-la inteligível às autoridades, a fim de que as autoridades possam tornar-se sensíveis a elas.

Para os fins da publicação deste trabalho, toma-se, como referência, a conotação mais ampla da palavra laudo, no sentido de "aprovo" (FERREIRA, 1975), observo a "norma," o "preceito" e todas as analogias referentes ao julgamento (AZEVEDO, 1983), pois são conteúdo e continente da incumbência, responsabilidade a ser contabilizada pelo autor do trabalho. Pensamos o laudo como possibilidade de restauração ${ }^{4}$ de direitos que podem ser pensados como Direitos Humanos.

Nossa discussão fundamenta-se em experiências resultantes da elaboração do laudo antropológico produzido em função de conflitos e crimes em terras indígenas, quando as autoridades cheias de dúvidas, ou

\footnotetext{
${ }^{4}$ No sentido de "corrigir", instituindo prática até então não considerada, porque temos diretrizes plurais e práticas que não, necessariamente, observam o pluralismo.
}

Espaço Ameríndio, Porto Alegre, v. 2, n. 2, p. 194-258, jul./dez. 2008. 
BELTRÃO, MASTOP-LIMA e MOREIRA - De vítimas a indiciados ...

munidas de muitas (in)certezas perguntam: eles são índios? Eles têm direitos?

Chamamos atenção para o fato de que o laudo foi feito a muitas mãos, não apenas dos autores (Beltrão, Mastop-Lima e Moreira), mas das autoridades indígenas que falam com propriedade do conflito e de seus desdobramentos. Ao discutir esta e outras experiências, como antropólogas e advogado, o fazemos, como diz Geertz, por acreditá-las “... comuns e até universais entre os que se dedicam a trabalho semelhante, sendo portanto representativas de algo mais do que elas mesmas ou eu" (2001, p. 32).

Os laudos antropológicos estão em alta, especialmente pela necessidade de se observar preceitos constitucionais, muito mais que nos anos setenta, quando se falava timidamente da demarcação de terras indígenas ou em "devolução" de resultados de pesquisa, após a "descoberta" do método freiriano ${ }^{5}$. Entretanto, as dificuldades na caminhada do século XX ao XXI não diminuíram em função da experiência. Hoje, mais do que ontem, os profissionais da Antropologia são chamados por juízes, procuradores e comunidades para demonstrar isto ou aquilo. Tarefas que exigem tanto trabalho etnográfico quanto uma dissertação de mestrado ou tese de doutorado, mas que não podem e não devem apresentar-se como tal, pois perderiam o valor heurístico no momento de dirimir querelas. Falamos, pois de escritos políticos, de argumentos para "convencer" e sensibilizar autoridades judiciárias a prestar atenção aos Direitos Indígenas.

Apresenta-se, a seguir, o laudo elaborado ao processo que corre na Justiça Federal, em Marabá no sudeste do Pará - Brasil, ilustrativo da dificuldade de fazer cumprir preceitos legais em área de fronteira e do cuidado em elaborá-lo a partir dos interessados, cuja voz foi abafada em função dos equívocos que transformaram os Suruí Aikewára em indiciados quando no contexto são vítimas.

\footnotetext{
${ }^{5}$ Referimo-nos às propostas formuladas por Paulo Freire, sobre o assunto, consultar Freire (1975a, 1975b e 1975c).

${ }^{6}$ Porque usa do recurso da "tradução" apresentando a lógica das práticas que do contrário permaneceriam desconhecidas daquele que julga.
}

Espaço Ameríndio, Porto Alegre, v. 2, n. 2, p. 194-258, jul./dez. 2008. 
BELTRÃO, MASTOP-LIMA e MOREIRA - De vítimas a indiciados ...

\section{Por que o Laudo? ${ }^{7}$}

O Laudo Antropológico, ora apresentado, atende à solicitação da $\mathrm{Dr}^{\mathrm{a}}$ Ela Wieko Volkmer de Castilho, Subprocuradora Geral da República e Coordenadora da $6^{a}$ Câmara de Coordenação e Revisão do Ministério Público Federal $(\mathrm{MPF})^{8}$ e da Dr $^{\mathrm{a}}$ Eloisa Helena Machado, Procuradora da República em Marabá.

A Subprocuradora Geral da República, em 3 de junho de 2003, solicita ao Magnífico Reitor da Universidade Federal do Pará, Dr. Alex Bolonha Fiúza de Mello, apoio e colaboração no sentido de atuar nos conflitos e na defesa dos interesses das populações indígenas e, particularmente, na Área Indígena Sororó (AIS). A solicitação foi prontamente atendida pelo dirigente da Instituição que mandou baixar Portaria $N^{\circ} 1592 / 2003$, em 17 de junho de 2003, designando Jane Felipe Beltrão, Luiza de Nazaré Mastop-Lima e Hélio Luiz Fonseca Moreira, sob a coordenação da primeira para processarem os estudos e elaborarem os documentos requeridos pelo Ministério Público Federal.

\section{Negociação e produção do Laudo}

Após o cumprimento do ritual do Serviço Público Federal e referendo da Associação Brasileira de Antropologia $(A B A)^{9}$, em 15 dias, a UFPA autorizou a emissão de passagens e diárias, em nome de professores e pesquisadores. No dia 17 de junho de 2003, a equipe se deslocou para

\footnotetext{
${ }^{7}$ O laudo ora publicado refere-se ao Processo: IPL 145.03; Classe: 15600 Inquéritos Policiais; Partes: REQTE: Justiça Pública; REQDO: Conduta de subtrair, mediante agressão física e grave ameaça, bens dos nacionais Divino Eterno da Silva e sua esposa Juliana Ferreira Pagani; Situação: Apurar responsabilidades.

8 Cf. Ofício $\mathrm{N}^{\circ}$ 0235, 0236 e 0237/2003/CaDIM/MPF de 29 de abril de 2003 e Ofício $\mathrm{N}^{\circ}$ 348/2003/CaDIM/MPF integrantes do Processo N ${ }^{\circ}$ 010990/03/UFPA.

${ }^{9}$ Cf. Ofício No 111/ABA/2003 enviado ao Magnífico Reitor da UFPA pelo Presidente da Associação, Prof. Dr. Gustavo Sérgio Lins Ribeiro.
}

Espaço Ameríndio, Porto Alegre, v. 2, n. 2, p. 194-258, jul./dez. 2008. 
Marabá com vistas a proceder levantamento e coleta de dados necessários à elaboração do Laudo Antropológico.

Estivemos em Marabá no período compreendido entre 17 e 22 de junho de 2003, próximo passado, quando todas as providências necessárias à emissão do Laudo Antropológico requisitado foram tomadas. Após a primeira ida ao campo, Luiza de Nazaré Mastop-Lima esteve entre os Suruí Aikewára em três oportunidades. Por outro lado, a equipe esteve sempre à disposição dos interessados para eventuais esclarecimentos.

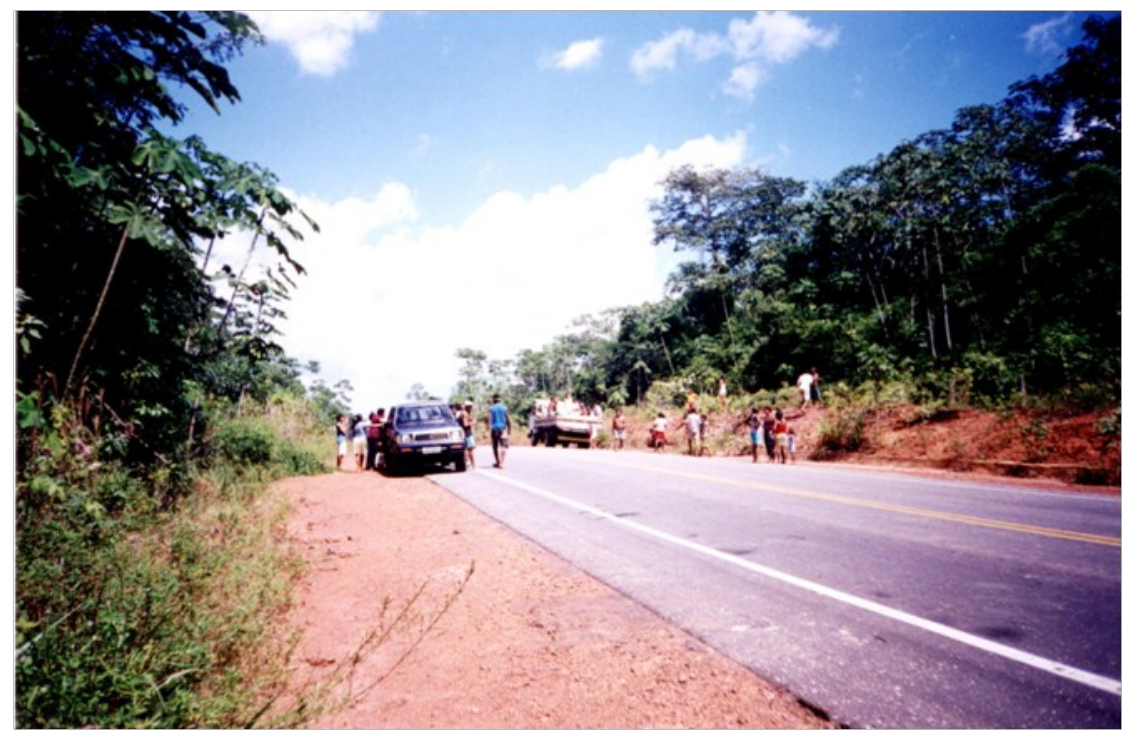

Foto 1

Entre as providências para dar cumprimento à solicitação de elaboração do Laudo, destaca-se o deslocamento a Marabá. Inicialmente, se ouviu as determinações da Procuradora da República em Marabá, Dra Eloisa Helena Machado, referentes à legislação em vigor, antes de tomar quaisquer outras providências relativas ao Laudo. A seguir, consultamos a documentação existente nos arquivos da Procuradoria e os técnicos da Instituição providenciaram todos os documentos solicitados.

Para a realização da perícia antropológica, foi imperativo o deslocamento diário da equipe à Área Indígena Sororó para ouvir e tentar compreender as ocorrências do dia 17 de março de 2003, do ponto de 
BELTRÃO, MASTOP-LIMA e MOREIRA - De vítimas a indiciados ...

vista dos protagonistas do conflito, no caso os Suruí Aikewára. E, para complementar as informações colhidas junto aos índios, realizou-se o reconhecimento da área do conflito posto que se precisava ver e analisar, em detalhe, o que vimos e ouvimos em campo.

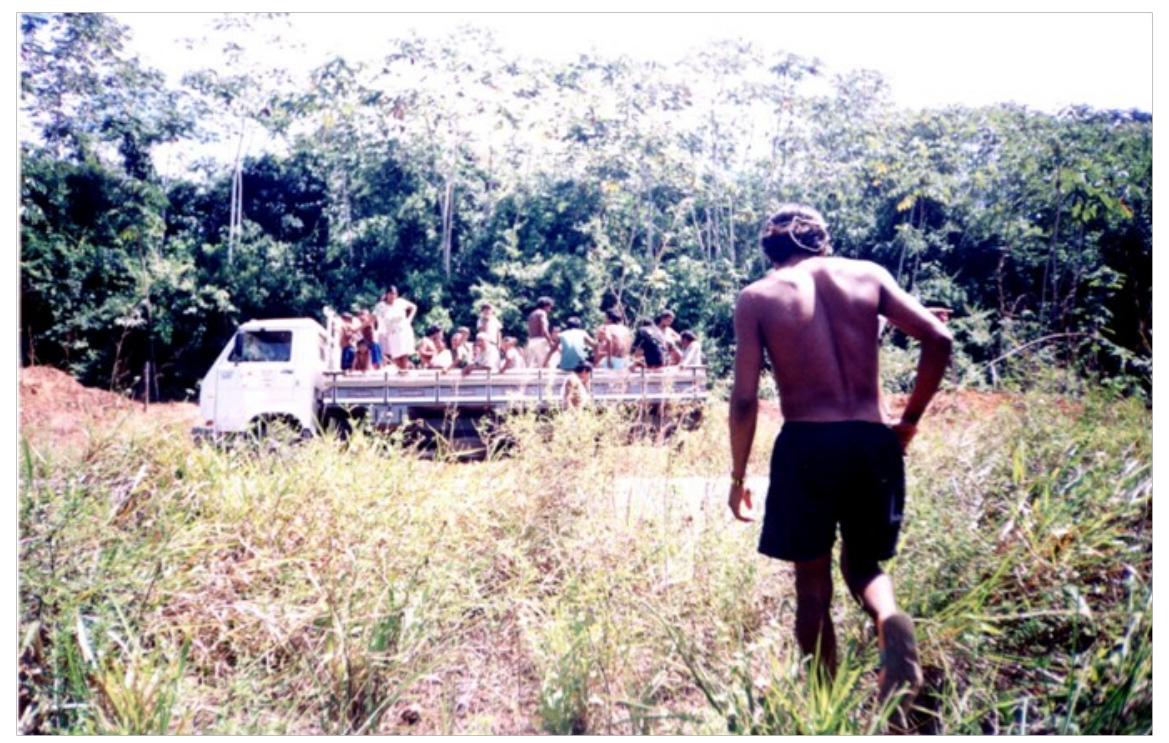

Foto 2

Percorreu-se a área do conflito, em companhia dos membros da comunidade destacados para a tarefa, exatamente no ponto de corte das terras Suruí Aikewára pela BR-153, identificando os locais apontados no Inquérito Policial. Vale ressaltar que, não apenas as pessoas destacadas nos acompanharam à área. Homens e mulheres, adultos e crianças, sem maiores cerimônia, lotaram o caminhão de propriedade dos Suruí (Fotos 1 e 2) e perambularam ${ }^{10}$, incansavelmente, conosco. A cada momento

\footnotetext{
${ }^{10}$ Chama-se perambulação a ação de indígenas que são obrigados a percorrer, a perambular cuidadosamente seu território em busca de caça, raízes comestíveis, frutos nativos, materiais para construção de suas moradias entre as múltiplas atividades quotidianas. Os indígenas perambulam, vagam, atravessam seu território trabalhando, buscando sustento diário. Entretanto, ainda hoje, a sociedade nacional toma esta cuidadosa ação dos grupos indígenas como “... perambulagem sem destino, procurando não se sabe o que ...”, pois, supostamente, nós, os ditos civilizados, sempre sabemos aonde ir e como ir, sem maiores delongas. É importante observar que os índios não restringem a perambulação à terra indígena (juridicamente regulamentada), mas continuam a usar o território (espaço que lhes pertence tradicionalmente, com o qual mantêm vínculos de pertença), gerando um sem número de conflitos. No caso dos Suruí Aikewára o fato é a expressão do que se afirma, pois as terras demarcadas, como Área Indígena Sororó, não correspondem ao território tradicional, bem mais extenso que, ainda hoje, os membros do grupo tentam reaver através da
}

Espaço Ameríndio, Porto Alegre, v. 2, n. 2, p. 194-258, jul./dez. 2008. 
BELTRÃO, MASTOP-LIMA e MOREIRA - De vítimas a indiciados ...

alguém indicava os locais e as paradas e todos tinham observações a fazer aos peritos, nada deixou de ser verificado. As narrativas sobre o evento são de domínio coletivo e aflige a todos indiscriminadamente. Outras informações foram coletadas em conversas na aldeia e durante as entrevistas coletivas concedidas em meio a reuniões com a comunidade na Casona (Fotos 3 e 4$)^{11}$.

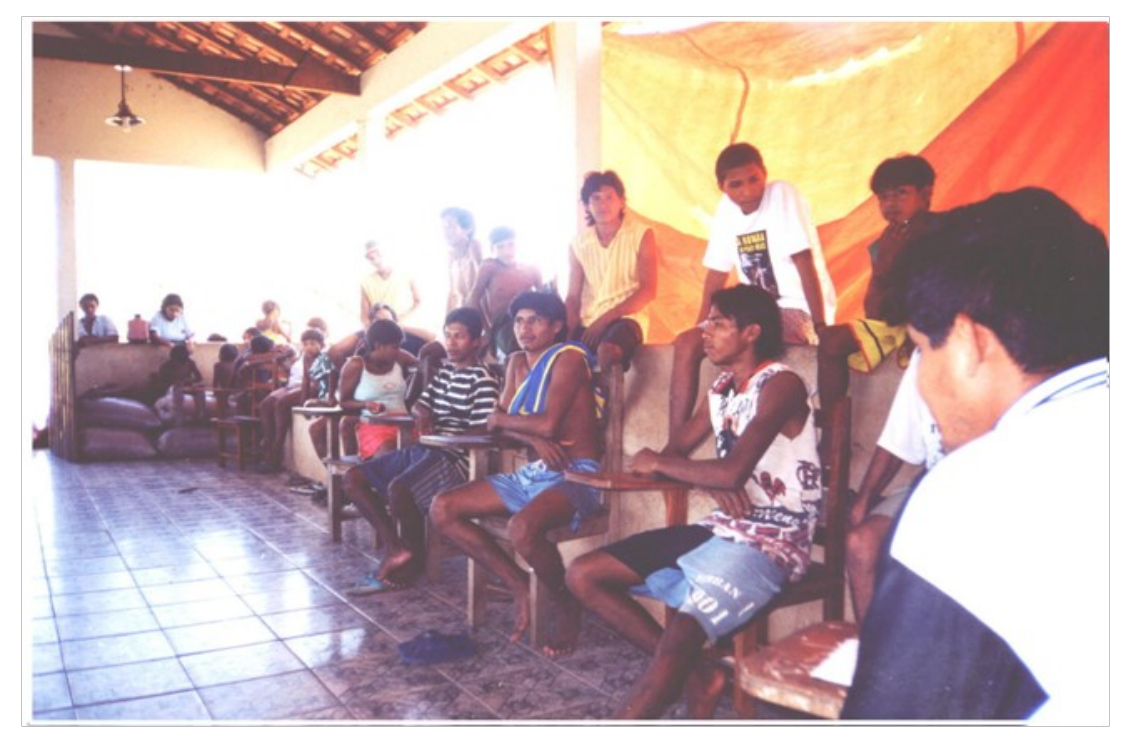

Foto 3

Trabalhou-se diretamente com os Suruí Aikewára na Área Indígena Sororó e, com os não indígenas, na extensão da BR-153 para constatar in loco o fluxo de veículos tanto no sentido São Domingos do Araguaia/São Geraldo do Araguaia, como no sentido inverso. Para melhor conhecer o movimento da rodovia percorreu-se o trecho, acima referido, observou-se o movimento de veículos em diversos horários e dias da semana,

\footnotetext{
revisão dos limites de suas terras. Dizem os Suruí que “... os antigo num pensava que ia crescer e ser muito ..." (Depoimento concedido em 17 de junho de 1998 a Jane Felipe Beltrão). O lamento é cruel e aponta para os erros praticados pelas autoridades responsáveis pela Política Indigenista do Brasil, país que não assume sua digna feição indígena plural e multifacetada.

${ }^{11}$ Espaço destinado à realização de reuniões de trabalho e festivas na aldeia. As reuniões são de livre acesso aos membros da comunidade que entram e saem dos eventos de acordo com as suas disponibilidades. Estando presente à reunião qualquer um dos Suruí pode intervir, especialmente se for considerado experiente e puder dar conselhos. Sobre as reuniões realizadas na Casona conferir Mastop-Lima (2002).
}

Espaço Ameríndio, Porto Alegre, v. 2, n. 2, p. 194-258, jul./dez. 2008. 
BELTRÃO, MASTOP-LIMA e MOREIRA - De vítimas a indiciados ...

fotografou-se a rodovia e a sinalização da mesma (Fotos 5 e 6), além de entrevistar os usuários, entre outras atividades.

Em meio às idas e vindas da Área Indígena Sororó se requereu, através da Procuradoria em Marabá, a documentação pertinente ao caso: processos referentes ao Inquérito Policial instaurado, atas de reunião para ajuste de conduta entre os Suruí Aikewára e o Governo do Estado do Pará, documentos produzidos pela Fundação Nacional do Índio (FUNAI), denúncias feitas pelos e/ou contra os Suruí Aikewára, e as fitas de vídeo e áudio gravadas pelas emissoras de televisão e rádio sobre a interdição da rodovia $B R-153^{12}$.

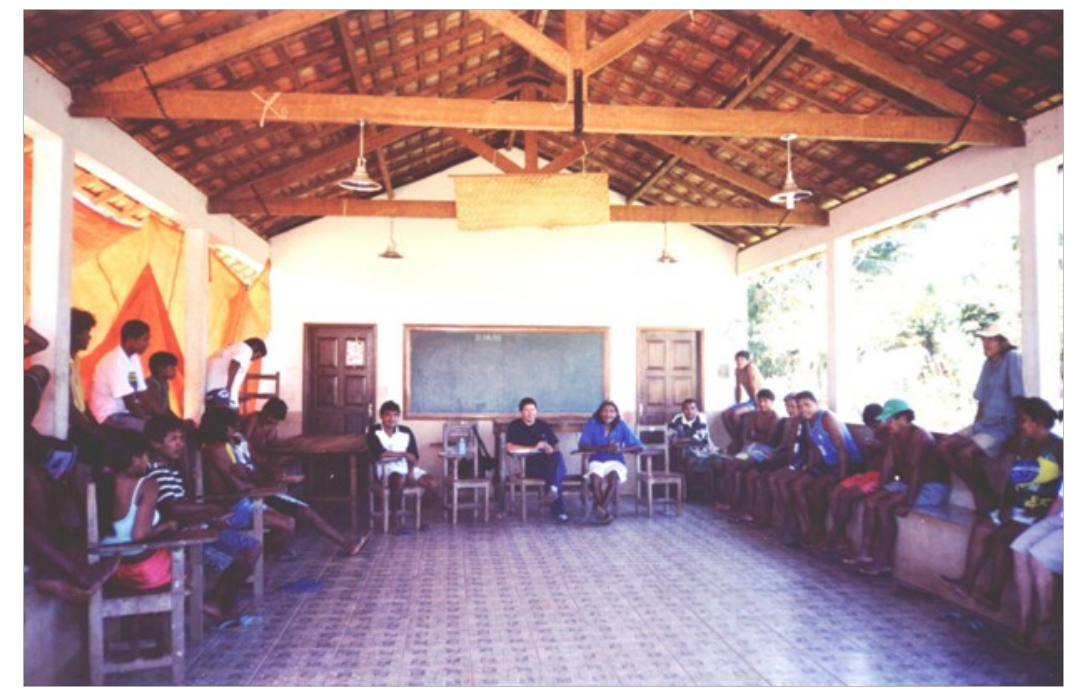

Foto 4

Entre os Suruí Aikewára conversou-se com os membros da comunidade diversas vezes, a partir de reuniões coletivas ${ }^{13}$, previamente agendadas, feitas a propósito do trabalho de elaboração do Laudo. Foram entrevistados todos os membros da comunidade apontados como conhecedores dos fatos ocorridos por ocasião da obstrução da rodovia. Alguns foram indicados pelas lideranças, outros se apresentaram

\footnotetext{
${ }^{12}$ Embora requerida, a documentação referente ao noticiário de rádio e televisão não pôde ser obtida. Os dirigentes dos veículos alegaram que as gravações não mais fazem parte de seus arquivos.

${ }^{13}$ Cf. Fotos 3 e 4, apresentadas anteriormente.
} 
BELTRÃO, MASTOP-LIMA e MOREIRA - De vítimas a indiciados ...

espontaneamente para tomar parte na conversa. Ouviu-se, também, todos aqueles que, tendo uma palavra a dizer, se manifestaram aos peritos. Processou-se o registro das queixas associadas ao acontecimento que abalou os indígenas.

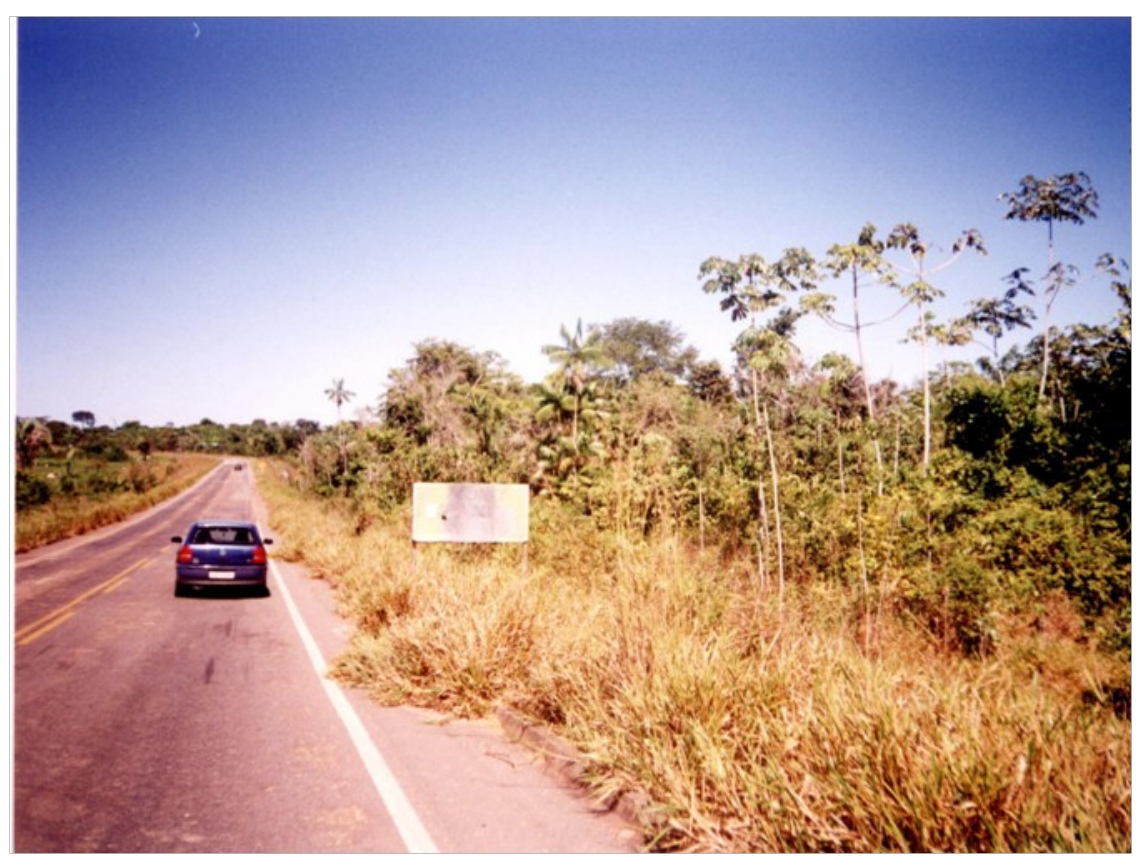

Foto 5

Os Suruí Aikewára têm conhecimento do Inquérito Policial. Das peças do Inquérito que mais causam indignação aos índios está o Boletim de Ocorrência feito na Delegacia de Polícia Civil em São Geraldo do Araguaia, inclusive pelo fato da queixa oferecida por Divino Eterno da Silva acusar Umassú ${ }^{14}$, Terí ${ }^{15}$ e Alex ${ }^{16}$. Sem compreender perfeitamente o ritual jurídico dos brancos, perguntavam e afirmavam: "por que eles? Quem disse o nome deles? Os nomes foram ditos pela FUNAI? Por que não tem o nome da

\footnotetext{
14 No passado próximo exerceu a chefia após a trágica morte de Sawarapí Suruí, pai de Mairá e Mahú, menores na ocasião. Guardião zeloso dos direitos do povo Suruí.

${ }^{15}$ Mãe de Alex, Arakapitã, Tatawirá, que estavam guarnecendo a barreira. Terí foi ouvida e chamada a conversar com a equipe porque seu filho Akarapitã ia sendo atropelado pelo caminhão de Divino Eterno e porque teve seu nome citado no Boletim de Ocorrência lavrado na Delegacia de São Geraldo do Araguaia.

${ }^{16}$ Filho de Tibakú e Terí que se encontra abalado pelo fato de ter sido ameaçado e ainda citado no documento lavrado na Funai em Marabá. Mesmo instado a falar, parece não compreender perfeitamente o que se diz.
}

Espaço Ameríndio, Porto Alegre, v. 2, n. 2, p. 194-258, jul./dez. 2008. 
BELTRÃO, MASTOP-LIMA e MOREIRA - De vítimas a indiciados ...

comunidade?" Se é necessário nomear, indicar, o nome a ser registrado deveria ser, segundo a lógica coletiva: Suruí Aikewára.

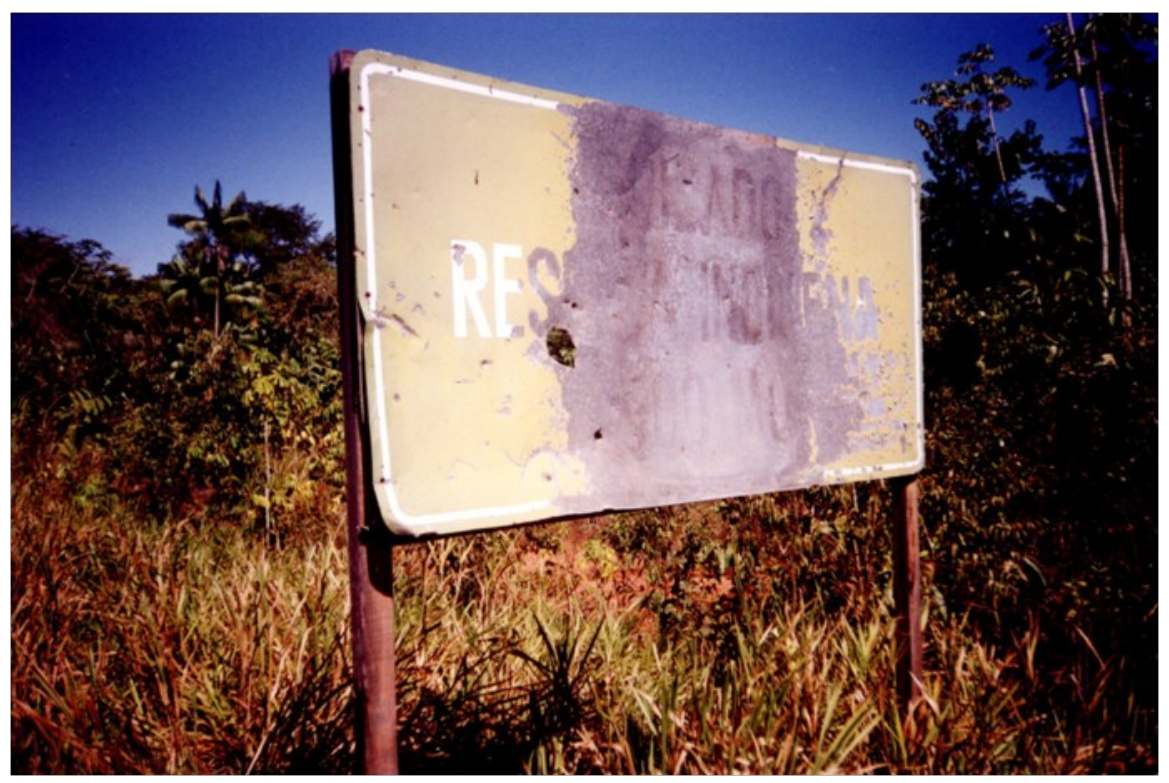

Foto 6

As dúvidas indignadas dos índios são fundamentadas no fato de que Aikewára não entra individualmente em conflito, como kamará (branco). Aliás, não apenas os Suruí Aikewára, outros povos indígenas têm a mesma dificuldade. Em outra ocasião, Topramre Krohokrenhum Jõpaipaire, líder Gavião Parkatêjê, declarou:

Eu quero contar, [como ocorreu o conflito] mas não posso. Parkatêjê é diferente de kupen [branco], [respira fundo, pita o tabaco e prossegue] kupen briga de dois, os outro olhá, assiste parado, nós não. Os nossos briga de bolo, todos da comunidade se joga, briga o bolo todo, ninguém sabe quem caceta quem. Eu não pode dizê que foi [olha à volta e com os olhos fixos no infinito da mata, informa] ele, aquele, não pode, não sei, nós luta pela terra, terra nossa ${ }^{17}$ (Depoimento colhido por Jane Felipe Beltrão em 04. 09. 2003, na aldeia Kupenjipôkti - grifos nossos).

\footnotetext{
${ }^{17}$ Para melhor compreender a lógica indígena consultar Beltrão (2001, 2002a e 2002b).
} 
BELTRÃO, MASTOP-LIMA e MOREIRA - De vítimas a indiciados ...

As decisões de romper o silêncio e reivindicar direitos foram coletivas e, como tal, devem ser entendidas. Os Suruí perguntam atônitos, "como os brancos, que em geral não gravam nome na língua [falam de sua Língua] aprendeu nosso nome?" E, eles mesmos respondem em coro: "alguém num disse, Terí, inda é bom, Alex é nome deles, mas Umassú, não alguém num disse!"

\section{Avivando a memória}

A saga dos Suruí Aikewára, viva na memória dos índios e esmaecida - por conveniência - na memória dos brancos, é bastante conhecida na área do Araguaia-Tocantins, pois seguidamente seu território tem sido invadido pelas frentes de expansão que alcançaram o sul do Pará. As terras que hoje constituem a Área Indígena Sororó, após renida luta, foram asseguradas pela Portaria da FUNAI $N^{\circ}$. 1.370/E de 24.09.1982, homologada através do Decreto No. $88.648 / 83$ de 30.08.1983 e registrada no SPU/PA No. 70, livro 2, às folhas 398-399 de 08.09.1986.

Mas, a demarcação não proporcionou tranqüilidade aos Suruí, pois desde a interdição da área em 1968, através do Decreto presidencial No. 63.367 de 08.10.1968 por iniciativa de Frei Gil Gomes Leitão, a interlocução dos índios com a sociedade nacional foi intensa e dramática ${ }^{18}$. Como informa Ricardo:

[f]oram os garimpos de cristal de rocha do baixo rio Araguaia que determinaram uma maior penetração no território tribal no começo do século. O confinamento dos Suruí na área onde hoje estão localizados ocorreu, entretanto, devido às pressões exercidas pelos castanheiros, a partir do início da década de 40, com incursões muitas vezes violentas (RICARDO, 1985, p. 103 - grifos nossos).

Dos "tempos antigos" os Suruí guardam marcas profundas, " pei ... pei... pei ..." ou "tum ... tum... tum ..." são onomatopéias referentes aos

\footnotetext{
${ }^{18}$ Para melhor conhecer a saga dos Suruí, consultar Ricardo (1985).
} 
BELTRÃO, MASTOP-LIMA e MOREIRA - De vítimas a indiciados ...

tiros de espingardas e revólveres que determinaram as perdas nos embates com invasores. Os sons perseguem, ainda hoje, os Suruí que ficaram órfãos, à época. As perdas não são, unicamente, físicas. Os danos de ordem emocional marcam, intensamente, o comportamento do grupo.

Laraia oferece uma avaliação dos acontecimentos:

[a]s violências sofridas em $1947^{19}$ e $1957^{20}$ não foram esquecidas, principalmente pelos parentes das vítimas. A devastação causada na aldeia pelos caçadores de peles é, hoje, reprovada pelos índios. E, o que é mais importante, os Suruí sabem que foram os Kamará [brancos] que introduziram na região as doenças que tantas mortes lhes causaram

É importante asseverar que nas décadas de 40 e 50 o contato com a sociedade nacional ainda não se fazia intensamente, apesar dos embates. A intensidade do contato só aconteceu a partir de 1960 quando desapareceram Musená, “... o velho e sábio chefe Suruí” (RICARDO, 1985) e outros velhos membros do povo Suruí Aikewára, vitimados pela gripe. A morte dos mais experientes produziu um clima de consternação na aldeia. O fato facilitou o jugo dos Suruí por João Correia $^{21}$, regional dedicado à caça de peles de animais silvestres, que levou muitos kamará à aldeia. A presença dos kamará produziu alterações irreversíveis, do ponto de vista da cultura tradicional, além da prostituição das mulheres indígenas e da dizimação do grupo, reduzido que foi a 40 indivíduos.

Os Suruí só se libertaram do jugo de João Correia ${ }^{22}$ e seus comparsas, graças à enérgica atuação de Frei Gil que, munido de procuração do antigo Serviço de Proteção aos Índios (SPI), expulsou os

\footnotetext{
${ }^{19} \mathrm{Na}$ década de 40, os grandes proprietários de terras no sul do Pará e os chefes políticos locais começaram a se estabelecer e a disputar os castanhais localizados em território Suruí passando a empreender expedições de extermínio contra o grupo, realizando emboscadas e queimando suas aldeias. Em 1947, ao tentarem aproximação com os castanheiros em Cajueiro foram recebidos à bala.

${ }^{20}$ Dez anos após Cajueiro, os Suruí foram recebidos à bala em Fortaleza às margens do Sororozinho afluente do rio Sororó.

${ }^{21} \mathrm{Na}$ verdade, João Correia era empregado assalariado de José Brito, negociante de peles, que pretendia transformar os Suruí em empregados para melhor esquadrinhar a floresta em busca de pele de animais silvestres. Sobre o assunto consultar Laraia e DaMatta (1967).

${ }^{22}$ Dias depois da expulsão, João Correia foi preso por latrocínio. Em 1967, segundo Laraia, encontrava-se preso, em Belém, aguardando julgamento. É provável, que jamais tenha sido julgado pelos crimes cometidos contra os Suruí. Sobre o assunto consultar Laraia e DaMatta (1967).
}

Espaço Ameríndio, Porto Alegre, v. 2, n. 2, p. 194-258, jul./dez. 2008. 
BELTRÃO, MASTOP-LIMA e MOREIRA - De vítimas a indiciados ...

invasores e garantiu a retomada, ainda que temporária de alguns costumes tradicionais. Mas, os Suruí que durante toda a sua existência, anterior ao contato, viveram de acordo com os seus costumes, de forma igualitária e em harmonia com a natureza, passaram a conviver com a penúria, a desigualdade e todas as mazelas produzidas pelo contato ${ }^{23}$.

A ocupação do Araguaia foi intensificada no final da década de 60 quando pequenos lavradores, expulsos de outros estados brasileiros, chegam em grandes levas ao sul do Pará. Era um momento crítico. Coincidiu com a construção de uma série de estradas novas e o aproveitamento e melhoria das estradas existentes ${ }^{24}$.

Para melhor compreender o quadro de mudanças, em 1971, foi entregue ao tráfego o trecho da rodovia Transamazônica que vai de Porto da Balsa ou Porto Jarbas Passarinho (à beira do Araguaia, pelo lado do Pará) a Marabá. Para além do Pará, abria-se uma via de comunicação com a Belém-Brasília, que ia de Tocantinópolis a Estreito. Apesar de acanhadas, as ligações sustentaram, desde a abertura, um pesado fluxo de veículos, especialmente, transporte de carga e coletivos de linha regular ${ }^{25}$. Mas, mesmo antes da entrega dos mencionados trechos, as alterações se faziam sentir. Em São Domingos do Araguaia, município onde está localizada a Área Indígena Sororó,

... serviu de acampamento de novembro de 1970 a fevereiro de 1971 para a firma empreiteira do trecho [Porto da Balsa/Marabá]. Eram mais de duzentos homens, criando um movimento nunca visto no povoado (VELHO, 1972, p. 146).

O canteiro de obras da ENGEPLAN, no final dos anos 90, reproduziu movimento e conseqüências semelhantes, quando foi promovida a ampliação e o asfaltamento da BR-153 (BELTRÃO, 1998a).

\footnotetext{
${ }^{23}$ Para conhecer, aprofundadamente, as agruras do contato entre os Suruí, consultar Laraia e DaMatta (1967) e Ricardo (1985)..

${ }^{24}$ Para conhecer o processo de penetração das frentes de expansão no sul do Pará, consultar Velho (1972).

${ }^{25}$ Em 1971, estabeleceu-se a primeira linha regular entre Porto da Balsa e Marabá, bastante concorrida e utilizada pelos moradores da área que iam e vinham em suas atividades de compra e venda. A linha não era muito regular, sobretudo, na época das chuvas, pois as estradas ficavam intransitáveis.
}

Espaço Ameríndio, Porto Alegre, v. 2, n. 2, p. 194-258, jul./dez. 2008. 
BELTRÃO, MASTOP-LIMA e MOREIRA - De vítimas a indiciados ...

A melhoria da malha viária da região trouxe algumas importantes conseqüências, pois o transporte de pessoas e mercadorias antes realizado pelo Tocantins e pelo Araguaia e seus afluentes, passou a ser realizado através das rodovias. Além disso, regiões antes inexploradas e/ou pouco exploradas dada a distância e a dificuldade de acesso, como os castanhais do Araguaia-Tocantins, passaram a ser inexoravelmente explorados. De outro lado, as rodovias proporcionaram:

... um maior afluxo de migrantes para a região, em busca de terra, não apenas pela facilidade de acesso, como também pela possibilidade de praticar uma agricultura voltada ao mercado, uma vez que agora, além do mercado regional, ainda incipiente, dispunham também de acesso a outros centros de consumo, principalmente Belém e outros situados mais ao sul, ao longo da rodovia Belém-Brasília (KITAMURA e MÜLLER, 1984, p. 11-12).

Sobre as mudanças, contam os Suruí que naquele tempo (meados da década de 70):

... ninguém falou nadinha. Começou pelo campo [pista de pouso], depois tinha a estrada, mas no inverno não dava p'ra eles passá. Daí era só pista, vrum ... vrum ... ${ }^{26}$. 0 finado meu irmão é que andava com eles [pessoal do exército], meu cunhado, o pai deles também, o velho Warini. Iam naquelas terra lá longe, era mata mesmo, eles levavu os velhinho p'ra mostrá, eles num sabia andá na mata. Era ra ... tá ... tá ...tá ... e lá ia os homê, mulhê, quem tivesse ${ }^{27}$. Eles eram mau. Os velhinho, igual criança, num sabia de nada, ia até o final mesmo. Até um tempo desse tinha uns quatro [guerrilheiros] enterrado aí. Naquela época eu tinha uns 10 p'ra 12 anos. Essa aí [BR153] eles [o exército] fizeru de primero no facão, daí à tarde tinha as máquina que chama moto, moto de serra.

\footnotetext{
${ }^{26}$ Imitando o barulho dos aviões. O depoente imitava a hélice de helicópteros e as asas de monomotores para assinalar o funesto bailado dos pássaros desconhecidos.

${ }^{27}$ Reproduzindo, dramaticamente, os sons de fuzis e metralhadoras do exército abatendo os guerrilheiros. Enquanto o informante narrava os fatos, os demais membros do grupo conversavam em Suruí muito emocionados. E diziam: "eles num sabiam", olhando para a antropóloga (Jane Felipe Beltrão), como se ela estivesse a acusá-los. Como a experiência foi drástica e, hoje, eles sabem mais sobre os acontecimentos, o grupo não quer ser acusado de "ajudar o exército à caça de guerrilheiros". Provavelmente, em algum momento eles foram acusados, daí a dificuldade de falar do assunto e a repetição do "eles não sabiam, eles eram como criança".
}

Espaço Ameríndio, Porto Alegre, v. 2, n. 2, p. 194-258, jul./dez. 2008. 
BELTRÃO, MASTOP-LIMA e MOREIRA - De vítimas a indiciados ...

derrubava as árvores, depois tinha outra máquina que deixava pronto. Foi assim qu'eles passaru aqui. Mas eles num dizia nada p'ra ninguém, vinho derrubando tudo, tudinho, daqui no São Geraldo. Depois que a gente prendeu as máquina, qu'eles fizeram o desmatamento, é qu'eles fizeram essa estradinha da aldeia. P'ra gente faz de conta que é dinheiro, naquele tempo não sabia de nada $^{28}$ _(Depoimento de Suruí, 17/06/1998 - grifos nossos).

Em 1972, com a eclosão da Guerrilha do Araguaia, o exército abriu diversas estradas operacionais ligando a Transamazônica ao Araguaia. A aldeia Suruí por sua estratégica localização serviu de base para a movimentação do exército. Inicialmente, um campo de pouso para pequenos aviões, posteriormente a estrada, conhecida como OP-2 e por último a transformação dos indígenas em batedores e guias das tropas que vasculhavam a área em busca dos guerrilheiros. Os militares acenaram com a possibilidade de garantir a demarcação e ampliação de suas terras, interditadas, à época, desde 1968. Passaram-se os anos e nada foi feito.

Na história do contato, a manipulação dos Suruí para envolvimento em "negócios de kamarâ" foi uma constante. Primeiro, João Correia e as peles silvestres; depois o exército e o combate à guerrilha; recentemente a ampliação e o asfaltamento da BR-15329. Mas, até hoje, estes atos que podem conduzir ao etnocídio, ao genocídio, não foram julgados. É importante observar que de 100 indivíduos que compunham o grupo, em 1961, existiam, apenas, 40 indivíduos. O grupo volta a crescer em 1969, passando a ser composto por 42 indivíduos. Se, em oito anos, o acréscimo populacional foi de dois indivíduos, a situação era gravíssima (RICARDO, 1985).

Em 1981, a OP-2 começou a ser ampliada pelo Batalhão de Engenharia Civil (BEC) atendendo aos interesses políticos do Major Sebastião Moura, conhecido na região como Major Curió, sobre Serra

\footnotetext{
${ }^{28}$ Conversa mantida com os Suruí onde os mais jovens relataram o passado, lamentando as ocorrências, em 17.06.1998. Sobre a utilização dos Suruí como batedores do exército, consultar Ricardo (1985).

${ }^{29}$ A saga Suruí Aikewára e a periodização aqui referida baseada na literatura sobre a região e nos depoimentos colhidos em campo não difere muito da encontrada por Magalhães (2002) para a situação dos camponeses do Médio Tocantins. (2002: 262).
}

Espaço Ameríndio, Porto Alegre, v. 2, n. 2, p. 194-258, jul./dez. 2008. 
BELTRÃO, MASTOP-LIMA e MOREIRA - De vítimas a indiciados ...

Pelada. A partir daí, os Suruí não mais tiveram paz, sem direitos foram sistematicamente pisados.

A OP-2, depois PA-253, hoje BR-153, constituiu o início de uma longa história de perdas não negociadas que os Suruí Aikewára foram obrigados a enfrentar. Ao longo de 26 anos nenhum reparo pelas perdas sucessivas de parte do seu território foi feito. Em todos os momentos, os Suruí tiveram seus direitos violados, jamais foram ouvidos sobre esta ou aquela fatia de território violado, cedido ou destruído. Algumas perdas são irreparáveis, tanto que, ainda, suscitam demandas e estão a exigir reparos. Apesar da equipe conhecer a situação, a avaliação do assunto foge ao Laudo Antropológico, ora apresentado. Para dirimir dúvidas a literatura histórico-antropológica está à disposição dos interessados ${ }^{30}$.

Cabe à equipe responsável pelo Laudo discutir, no presente documento, a BR-153 e sua repercussão em relação à Área Indígena Sororó para contextualizar as ocorrências do 17 de março de 2003, caso Divino Eterno. Retoma-se a discussão a partir da abertura em 1972, uma vez que nada foi feito para resguardar os direitos dos Suruí, até dezembro de 1997. Na ocasião, a Procuradoria da República em Marabá, através de sua titular, interpelou o Governo do Estado do Pará sobre o alargamento e asfaltamento da rodovia sem que o Estudo de Impacto Ambiental e o Relatório de Impacto Ambiental (EIA/RIMA) tivesse sido feito.

Retornando à memória avivada, a abertura do campo de pouso no coração do território Suruí e a abertura da OP-2 em 1972 rasgando a Área Indígena Sororó numa extensão de $11 \mathrm{~km}$, cortou o mais produtivo castanhal indígena, acarretando prejuízos, até hoje, não calculados. O outrora produtivo castanhal Suruí localiza-se no chamado Polígono da Castanha, área disputadíssima no sul do Pará, dado o seu significado político-econômico ${ }^{31}$.

Em 1998, foi realizado um levantamento da produção do castanhal das terras Suruí Aikewára, colocação ${ }^{32}$ a colocação, antes e depois da

\footnotetext{
${ }^{30}$ Considera-se que a revisão dos limites da Área Indígena Sororó é urgente, mas há um grupo de trabalho analisando $o$ assunto.

${ }^{31}$ Para uma discussão aprofundada sobre o Polígono consultar Emmi et al (1987).

${ }^{32}$ Lugar dentro do castanhal, onde se concentram castanheiras nativas, também conhecidas, como bola de castanha, no sul do Pará.
}

Espaço Ameríndio, Porto Alegre, v. 2, n. 2, p. 194-258, jul./dez. 2008. 
BELTRÃO, MASTOP-LIMA e MOREIRA - De vítimas a indiciados ...

\begin{abstract}
passagem da BR-153 (Tabela 1) na tentativa de demonstrar a importância do mesmo para a economia do grupo.
\end{abstract}

CASTANHAL SURUÍ AIKEWÁRA (no corte da BR-153, sentido Aldeia/Gameleira) ${ }^{33}$

\begin{tabular}{|c|c|c|}
\hline Colocação $^{34}$ & Localização/Margem $^{35}$ & Produção (em hl) \\
\hline 01. Pau Preto & $\mathrm{km} 1^{36}$ & improdutivo \\
\hline 02. Água Fria & $\mathrm{km} 3$ & 40 \\
\hline 03. Cupú & $\mathrm{km} 4$ & 20 \\
\hline 04. São Joaquim & $\mathrm{km} 6$ & improdutivo \\
\hline 05. São Raimundo & $\mathrm{km} 6$ & improdutivo \\
\hline
\end{tabular}

TABELA 1

Tomando como base uma produção anual de 1.200 a 1.300 hectolitros de castanha $^{37}$ a queixa tem fundamento: a produção de castanha foi reduzida em mais de $70 \%$. A cada ano, os Suruí deixam de ganhar, pelo menos, o correspondente a 950 hectolitros de castanha. Durante 26 anos (até 1998), a comunidade deixou de receber o correspondente a 24.700 hectolitros de castanha. Considerando o preço da safra (em 1998) R $\$ 30,00$ (trinta reais) por hectolitro, os Suruí deixaram de receber $\mathrm{R} \$ 741.000,00$ (setecentos e quarenta e um mil reais).

\footnotetext{
${ }^{33}$ As informações foram coletadas através de depoimentos dos membros dos Suruí Aikewára e observação direta das colocações ao longo da BR-153 feitas pelo engenheiro florestal Carlos de Araújo Loureiro Júnior da FUNAI e pela antropóloga Jane Felipe Beltrão. Arumã (Filho de Awariní, um dos guerreiros mais velhos; responsável pelo uso dos motores que fornecem água e energia elétrica para a aldeia) e Itamaré (Filho de Wa'á - Vovozinha - moço andarilho que viveu parte de sua vida fora da aldeia. Pelo fato de conhecer o "mundo dos brancos" os Suruí lhe conferem o status de consultor quando o assunto diz respeito a "negócio de kamará", tanto que ele era o procurador de Wa'a.) foram os informantes principais, destacados pela comunidade para acompanhar o trabalho técnico. Não foi possível fazer um levantamento mais profundo, porque os mais experientes não podem mais oferecer informações, afora o fato da comunidade não dispor de registros escritos. Para uma visão aprofundada da produção de castanha no sul do Pará consultar Beltrão (1998b).

${ }^{34}$ No caso, estão listadas, unicamente, as colocações que ficam às margens da BR-153.

${ }^{35}$ A passagem da rodovia, na década de 70 , produziu o corte das colocações de castanha. $\mathrm{O}$ fato determinou a drástica redução das safras anuais.

${ }^{36} \mathrm{O}$ corte produzido pela rodovia, algumas vezes, reduziu o tamanho da colocação a uma das margens da BR153.

${ }^{37} \mathrm{O}$ cálculo foi feito tomando por base: as menores safras obtidas pelos Gavião Parkatêjê; a extensão das terras Suruí Aikewára; e os valores obtidos pela FUNAI com a venda da produção Suruí em 1974/1975. Sobre o assunto consultar Beltrão (1998b) e Ricardo (1985).
}

Espaço Ameríndio, Porto Alegre, v. 2, n. 2, p. 194-258, jul./dez. 2008. 
BELTRÃO, MASTOP-LIMA e MOREIRA - De vítimas a indiciados ...

Há grande probabilidade da produção ter sido maior no passado, pois como informam os interessados:

desapareceu muito ... por dia eles derribarum, naquele tempo das moto serra e das máquinas, mais de dez pé de castanheira, foi muito mesmo. Quando começou a 'queimá' pasto ${ }^{38}$, acabou castanha, cupú ${ }^{39}$, cacau e até no Água Preta $^{40}$ eles queimarum. Tudo é assim fino ${ }^{41}$, queimô não dá mais, mesmo que num derrube ... ${ }^{42}$ (Entrevista com Suruí, 02/09/1998).

Infelizmente, não há registros sobre a produção, nem da época em que a FUNAI era responsável pela comercialização da safra de castanha dos Suruí. Sabe-se, apenas, que:

o valor arrecadado com a comercialização da castanha era assim distribuído: $45 \%$ do total deveria ser aplicado no próprio PI [Posto Indígena]; $10 \%$ corresponderia ao "dízimo", isto é a quantia que a Delegacia retirava dos Postos produtivos e deveria enviar àqueles improdutivos; desconhecia o destino dado aos $45 \%$ restantes (RICARDO, 1985, p. 111 - grifos nossos).

É previsível que a FUNAI não se ocuparia da produção Suruí se os lucros não justificassem o 'dízimo' e mais os $45 \%$ que o órgão não informa o destino.

Outra via de cálculo é tomar o espaço da rodovia, ou seja, $11 \mathrm{~km}$ de comprimento por $100 \mathrm{~m}$ de largura, assim a perda corresponde a 110 hectares ${ }^{43}$. Considerando, ainda, que o castanhal Suruí encontra-se no

\footnotetext{
${ }^{38}$ A "queimá" significa colocar pasto, 'plantar' pasto. Como a queimada precede a colocação do pasto e a queimada traz inúmeros prejuízos, na região fala-se em "queimá pasto".

${ }^{39}$ Cupuaçu (Theobrona grandiflorum) do Tupi kupua'su ou cupu grande. Fruta comestível de grande valor comercial.

${ }^{40}$ Refere-se à colocação Água Preta, uma das mais produtivas do território Suruí, cortada pela OP-2, hoje BR-153.

${ }^{41}$ Diz-se que algo da flora é 'fino' quando sua sensibilidade é alterada pelas circunstâncias ambientais. No caso, a castanheira, o cupuaçuzeiro e o cacaueiro são sensíveis ao fogo. No que se refere à castanheira, o fogo afugenta, faz desaparecer os insetos polinizadores, causando danos irreparáveis à produção.

${ }^{42}$ Conversa mantida com os Suruí, em 02.09.1998, quando os mais experientes relataram o passado lamentando as ocorrências.

${ }^{43}$ Os dados que apresentamos a seguir foram calculados com o inestimável auxílio do Centro Agro-Ambiental do Tocantins (CAT), através do educador Emmanuel Vamberg, profundo conhecedor da região que trabalha com pequenos agricultores há mais de 25 anos, e do engenheiro agrônomo Anísio Augusto de Souza Moura, o
}

Espaço Ameríndio, Porto Alegre, v. 2, n. 2, p. 194-258, jul./dez. 2008. 
BELTRÃO, MASTOP-LIMA e MOREIRA - De vítimas a indiciados ...

Polígono da Castanha e que a ocorrência na área é de uma castanheira por hectare e que a produção anual é 0,5 hectolitros, teoricamente ter-se-ia: 110 castanheiras, produzindo 55 hectolitros de castanha, que poderiam ser vendidos a $R \$ 30,00$ (trinta reais) o hectolitro, preços de 1998. A comunidade receberia $R \$ 1.650,00$ ( hum mil seiscentos e cinqüenta reais) ao ano. Em 26 anos as perdas somam R\$42.900,00 (quarenta e dois mil e novecentos reais). Como o Laudo anterior foi feito em 1998, hoje deveriam somar-se mais cinco anos, posto que os valores, negociados à época ainda não foram pagos. Está é uma das razões da constante tensão na área.

Embora se saiba que "a produtividade das castanheiras apresenta variação de 0,16 a 0,55 hl/ha de castanha com casca, se considerar o conjunto da área do castanhal" (KITAMURA e MÜLLER apud HOMMA et al, 1996, p. 528). E "a densidade de castanheiras varia entre 33 a 107 castanheiras adultas por lote de 50 ha" (HOMMA et al, 1996, p. 528). Observe-se que tanto Kitamura e Müller, como Homma et al, referem-se a castanheiras em lotes de colonos e não em extensas áreas como no caso em estudo. Portanto, as estimativas estão aquém dos prejuízos produzidos. Além disso, não se tratou, aqui, da questão da reprodução das castanheiras e dos estragos produzidos pelas queimadas tão freqüentes no sul do Pará.

A avaliação da produção entre os Suruí Aikewára ou em qualquer outra área indígena fica prejudicada, porque as estatísticas, oficiais ou não, sempre deixaram de lado a produção oriunda de terra ou território indígena. No primeiro caso por estar sob jurisdição da FUNAl e, no segundo, pela impossibilidade de controlar a produção quer da coleta feita pelos índios, quer da coleta executada pelos brancos, sobretudo porque, no último caso, é fruto de saque ou roubo, fato jamais declarado. Invariavelmente, os pesquisadores alertam que nas tabelas apresentadas não estão incluídas as áreas sob jurisdição da FUNAI (HOMMA et al, 1996). Aliás, se computados os dados das áreas sob jurisdição da FUNAI, dificilmente os mesmos poderiam ser confiáveis. Isto é especialmente

qual também desenvolve trabalho junto aos pequenos agricultores da região do Tocantins. Registre-se, na oportunidade, especial agradecimento a Jean Hébette, coordenador do CAT, e sua equipe que não pouparam esforços para cooperar com a elaboração do Laudo elaborado em 1998 a propósito da BR-153.

Espaço Ameríndio, Porto Alegre, v. 2, n. 2, p. 194-258, jul./dez. 2008. 
BELTRÃO, MASTOP-LIMA e MOREIRA - De vítimas a indiciados ...

correto no caso dos Suruí, pois durante anos a comunidade lutou com os desvios de castanha feitos por funcionários do órgão tutelar. Fato sempre presente no depoimento dos líderes, especialmente, ao referirem a retomada da comercialização da castanha (sem intervenção da FUNAI), nos idos dos anos 70, com a assessoria da antropóloga lara Ferraz.

A julgar pelas observações de Homma et al (1996), o castanhal Suruí é extremamente viável: “... a viabilidade da extração de castanha-do-pará naquela região [sul do Pará] depende da existência de grandes áreas". Prosseguem dizendo, "a atual ênfase que se coloca na transformação dos estoques de castanhais em propriedade comum, como se propõe com a criação das reservas extrativistas, quando este recurso se torna escasso não assegura a sua conservação e a preservação da floresta" (HOMMA et al, 1996, p. 519).

Durante 26 anos (até 1998) os Suruí Aikewára assistiram à invasão de seu território, à abertura da rodovia, à passagem dos veículos, ao aumento do tráfego, às sucessivas interrupções do trânsito durante a época das chuvas e, nos últimos cinco anos, às providências referentes ao alargamento e asfaltamento da BR-153, sem que nenhum representante do Governo federal ou estadual negociasse a passagem da rodovia pela Área Indígena Sororó em franco desrespeito aos direitos indígenas.

Os Suruí esperaram, ansiosos, o momento de negociar. Negociaram, como manda a diplomacia Tupi, em 1998, acreditaram na palavra do Governador do Estado à época, o médico Almir Gabriel. Mas os valores da negociação a serem pagos sob forma de benefícios à comunidade não chegaram. Da indenização devida, a construção da nova aldeia é a mais reivindicada. Mairá e seus companheiros por diversas vezes demandaram explicações do MPF, expressando o desejo dos Aikewára.

Sobre a rodovia, apesar de discordarem do corte feito na Área, os índios entendem que a rodovia é irreversível e necessária a eles e aos habitantes da região, pois proporciona ligações rápidas com os centros mais próximos, especialmente, em casos de urgências médicas. A nova rota reduz em muito o tempo de permanência de pessoas estranhas dentro da área, visto diminuir o número de veículos quebrados ou parados diante 
BELTRÃO, MASTOP-LIMA e MOREIRA - De vítimas a indiciados ...

de atoleiros. Auxilia o escoamento da produção de castanha-do-pará e de frutos regionais, proporcionando ainda, o transporte de produtos essenciais à comunidade. Mas, apesar de entenderem a importância do empreendimento, esperam ter seus direitos assegurados com o auxílio do Ministério Público Federal e a compreensão dos governantes do Estado e da União (BELTRÃO, 1998a).

$\mathrm{Na}$ verdade, pela lógica Aikewára, a rodovia é importante, mas as providências devem ser tomadas sem colocar suas vidas em risco. E a lógica indígena, reivindica ainda hoje, a colocação de lombadas, sonorizadores, passagens subterrâneas, entre tantas alternativas propostas para minimizar os problemas causados pela BR-153. Como diz Mahú, ao contar como Divino Eterno passa em suas terras,

... carretero carrega pedra pra cá, de Tucuruí, anda no escuro aí, com lua bonita. Quando a lua tá bonita eles não acende farol não, passa no escuro mesmo, só prá matar os bichos aí. Aí a gente fica preocupado. Aí, é que naquele tempo [época da elaboração do Laudo, 1998] foi pedido também sonorizador né? Ou quebra-mola mesmo, pelo menos aqui na estrada [entrada da Aldeia] e lá na saída [à altura do rio Gameleira], lá também ... (Entrevista com Mahú, 19/06/2003).

Sabe-se que as rodovias são fundamentais para a "integração" das diversas regiões do país e, sobretudo em se tratando do sul do Pará. Mas a suposta "integração" não pode desconhecer o direito das minorias étnicas e/ou sociais que compõem o variado mosaico étnico do Brasil. Os Suruí Aikewára esperaram, pacientemente, há 31 anos, apesar das ações diretas, em quatro ou cinco oportunidades ${ }^{44}$. Tentaram sempre evitar quaisquer transtornos à população das circunvizinhanças da Área e, mesmo, à

\footnotetext{
${ }^{44}$ Chama-se ação direta ao ato de "entupedinir"(obstruir) a rodovia como forma de chamar atenção às suas reivindicações. Os Suruí volta e meia perguntam aos mais próximos se não podem cobrar pedágio pela passagem dos veículos em suas terras. Afinal, o território que lhes pertence foi violado e ninguém os ouve. Em uma das muitas das vistorias solicitadas pelo MPF em Marabá, Jane Felipe Beltrão foi interpelada: "se a pista [rodovia BR-153] entrasse na sua casa?" Como a antropóloga ficou sem saber o que dizer a eles que insistiam: "na [casa] do Almir [Governador do Estado à época] não passou, né?" O argumento é pertinente, eles sabem que são tratados sem respeito e referem especificamente Almir Gabriel, porque confiaram na palavra da autoridade que prometeu cumprir as determinações do Laudo Antropológico para "encurtar" as dificuldades referentes à ampliação e asfaltamento da rodovia. Os Suruí confiaram na autoridade, afinal ele garantiu!
}

Espaço Ameríndio, Porto Alegre, v. 2, n. 2, p. 194-258, jul./dez. 2008. 
BELTRÃO, MASTOP-LIMA e MOREIRA - De vítimas a indiciados ...

política do Estado. Como já vai longe o tempo do "integrar para não entregar" urge reparar o ultraje sofrido, pelos Suruí Aikewára, com a perda de aproximadamente 200 hectares de território.

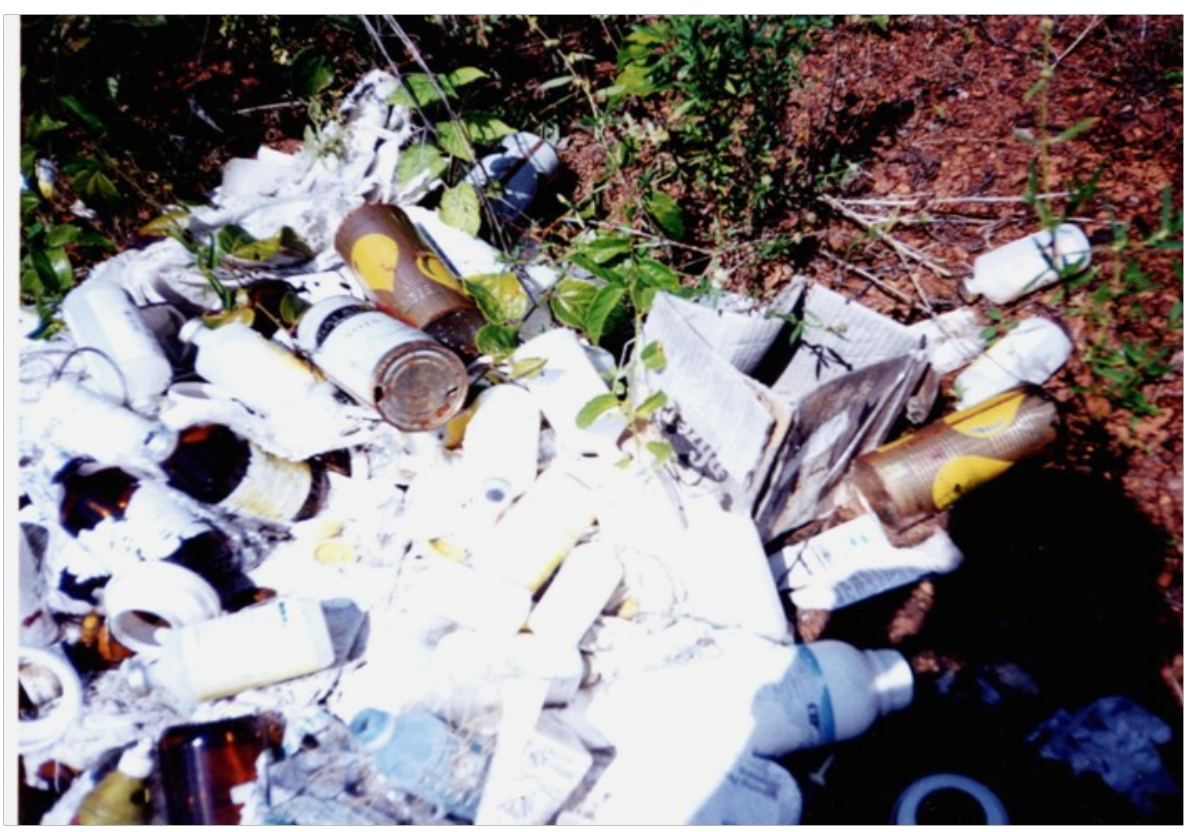

Foto 7

E entristecido, sem perder a altivez e a seriedade de líder, Mahú informa:

atrás de tudo isso que nós esquecemo [no sentido de "fingir que"] aí, Jane ${ }^{45}$. Tem muitas pessoa, acha que índio pede muito né, né falta de pedi não, acho que é obrigação do governo de fazer isso pra nós, coisa que precisa aqui, coisa que nós tem direito de cobrar (Entrevista com Mahú, 19/06/2003).

E para mostrar que nem todos agem da mesma forma, Mahú completa:

e também nós ... nós pedimo pras pessoa que passava aqui, que tava trafegano aqui né, pedimo: "olha nós vamo fechar aqui essa estrada. Só que nossa manifestação nós

\footnotetext{
${ }^{45}$ Refere-se à Jane Felipe Beltrão, antropóloga responsável pela elaboração do Laudo Antropológico de 1998.
} 
BELTRÃO, MASTOP-LIMA e MOREIRA - De vítimas a indiciados ...

não querendo brigar com ninguém. Por que não tem nada a ver. Nós vamo brigar com os pessoal representante lá, com os secretário do governo lá". Nós falemo pra eles. "Vocês não têm nada a ver. Por que a PA passa por aqui". E muitas pessoa ficou com raiva ainda por causa disso. É que nós tem direito de cobrar das coisa que era pra ser feita. E não foi feito nada até agora. É ... então que ... você dá mais uma força aí pra nós Jane ${ }^{46}$, que ... pra tomar mais providência, mais rápido aí pra ... e os caminhonero não atropelar mais aí nossos animal né, e também queria que você aproveitasse e pedisse pra prefeitura aqui desse município, aqui vizinho que achasse um local, assim, pra que esses moradores jogasse o lixo ${ }^{47}$ deles, não jogasse aqui na reserva porque tá contaminando aqui nosso ... nosso ... nossas caças, cutia, jabuti, essas coisa aí gosta de comer lixo velho. E também nós tem castanhal pra lá também. E tem uns pessoal que tira, tira planta também, tira castanha pra lá, aí ... lá onde eles joga lixo, lá é pasto, lá, e quando chove carrega tudinho lá pra baixo. Com certeza eles bebe água contaminada lá (Entrevista com Mahú, 19/06/2003 grifos nossos).

Os Suruí se apercebem que há brancos e brancos. Alguns são kamará punura $^{48}$ (branco mau) outros não. Uns são respeitosos, outros nem tanto. Mas, no geral enfrentam o desrespeito quotidianamente. Assevere-se que o desrespeito ultrapassa o insulto, compromete as relações sociais, ameaça a sobrevivência dos Aikewára.

Fazendo coro com Sydenstriker Neto (1992) observa-se que:

[n]os últimos anos, as nações indígenas, bem como o movimento dos seringueiros têm conseguido com extraordinária habilidade politizar e dar uma dimensão planetária para os processos em curso na Amazônia. Em grande medida através da atuação de suas organizações, a ocupação da Amazônia deixou de ser campo exclusivo de exercícios de estratégias de segurança nacional. Por outro lado a visão da Amazônia enquanto vazio demográfico e social que exige ocupação (integrar para

\footnotetext{
${ }^{46}$ Refere-se, novamente, à antropóloga Jane Felipe Beltrão, instando-a a requerer o cumprimento das reivindicações presentes no Laudo de 1998.

${ }^{47}$ Ver Foto 7.

${ }^{48}$ Kamará punura é o termo usado pelos Suruí para designar homem branco mau, aquele que não respeita as pessoas, as normas e os valores socialmente instituídos.
}

Espaço Ameríndio, Porto Alegre, v. 2, n. 2, p. 194-258, jul./dez. 2008. 
BELTRÃO, MASTOP-LIMA e MOREIRA - De vítimas a indiciados ...

não entregar), mostrou-se infundada. Os povos da Floresta têm revelado não apenas que existem e ocupam. a região, mas que possuem profundo conhecimento do meio que habitam e propostas de aproveitamento dos recursos (SYDENSTRICKER NETO, 1992, p. 49 - grifos nossos).

A rodovia produziu um corte de $11 \mathrm{~km}$ na floresta nativa, do território Suruí ${ }^{49}$, estendendo-se por mais de $100 \mathrm{~m}$ de largura. A largura foi calculada considerando a rodovia em si, o acostamento e as áreas de domínio da empresa rodoviária ${ }^{50}$.

Ao longo dos $11 \mathrm{~km}$ de corte é possível, ainda, encontrar uma área degradada pela retirada de piçarra necessária aos trabalhos da rodovia, cuja recuperação ambiental não foi providenciada até a presente data, e que foi alvo de tentativa de negociação entre os Suruí e a ENGEPLAN ${ }^{51}$. A negociação, considerada irregular, foi interrompida pela enérgica ação da titular do Ministério Público em Marabá. A área degradada foi avaliada por técnico do Ministério ${ }^{52}$. Decorridos cinco anos, a situação não mudou. A equipe esteve em campo e pôde observar a área, segundo nossos informantes o local de onde foi retirada a piçarra é campo de "treina de tiro", os índios informam que são surpreendidos pelo barulho na calada da noite, os curumins escalam o local para mostrar os buracos (Foto 8). A cena é chocante! Pensando alto, o conflito é permanente.

\footnotetext{
${ }^{49}$ Sem contar a área que serviu de apoio à abertura da estrada, qual seja o campo de pouso no centro da Área, invadindo a aldeia e alterando substancialmente o quotidiano Suruí Aikewára.

${ }^{50}$ As medidas foram tomadas pelo funcionário Josimar do L. Moraes Mendes, chefe do Posto Indígena Flexeira na Reserva Indígena Mãe Maria, da Administração Regional da FUNAI, em Marabá, em 18 de junho de 1998, designado que foi a acompanhar as antropólogas Jane Felipe Beltrão (UFPA) e Maria Fernanda Paranhos Paula e Silva (MPF).

${ }^{51}$ Empreiteira responsável pela ampliação e asfaltamento do trecho da BR-153 que atravessa a Área Indígena Sororó.

${ }^{52}$ A vistoria foi realizada pelo Engenheiro Florestal do Ministério Público Joanildo Santiago de Souza, que esteve na área em setembro de 1998. Para melhor compreensão do problema, consultar Informação Técnica $\mathrm{N}^{\mathrm{o}} 093 / 98-4^{\mathrm{a}} \mathrm{CCR}$.
}

Espaço Ameríndio, Porto Alegre, v. 2, n. 2, p. 194-258, jul./dez. 2008. 
BELTRÃO, MASTOP-LIMA e MOREIRA - De vítimas a indiciados ...

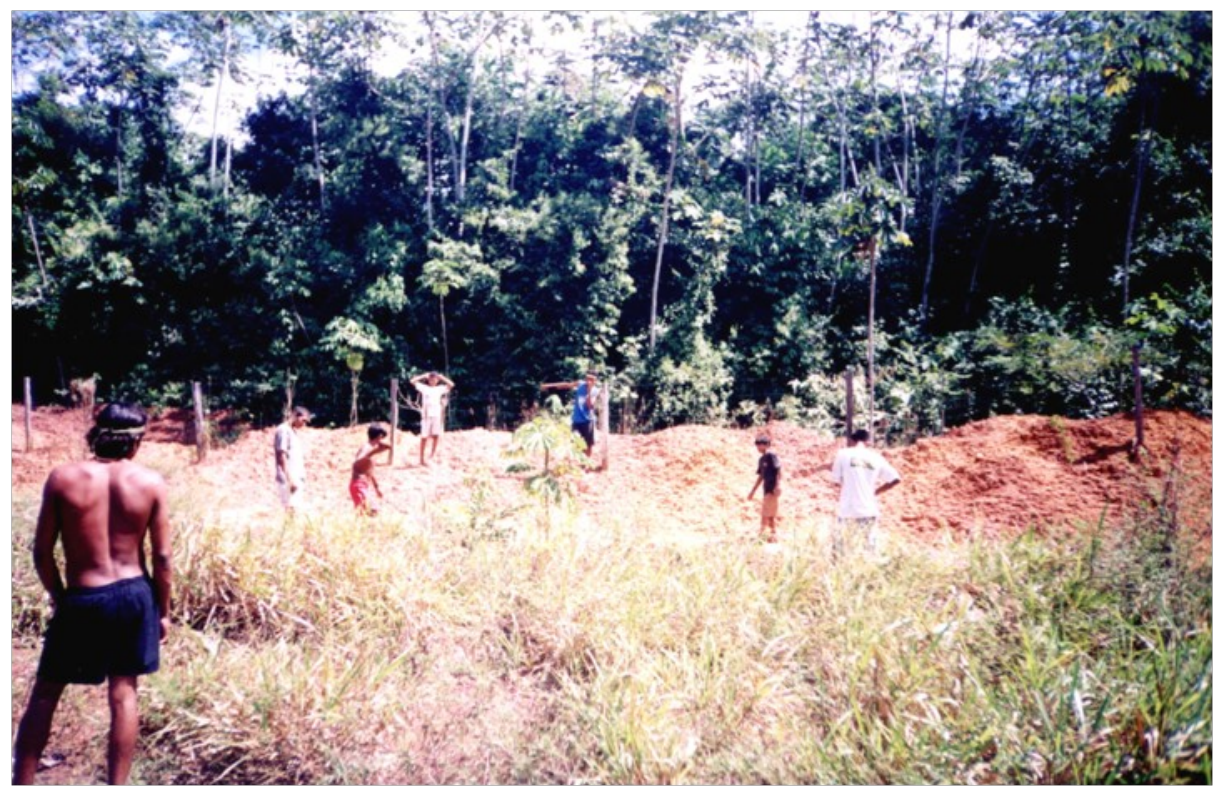

Foto 8

\section{Inquérito policial}

Após registro de ocorrência efetivado na Delegacia de Polícia Civil ${ }^{53}$, no município de São Geraldo do Araguaia, foi instaurado inquérito policial, na Delegacia de Polícia Federal, em Marabá/Pará ${ }^{54}$, através de Portaria $\mathrm{N}^{\circ}$ 146/03, de 9 de maio de 2003, no qual os Suruí Aikewára foram indiciados pela prática de roubo qualificado e lesão corporal ${ }^{55}$ contra Divino Eterno da Silva.

Para melhor situar a questão transcreve-se o Boletim de Ocorrência no qual se baseou o Delegado de Polícia Federal para instaurar o inquérito policial. O referido Boletim foi lavrado na Delegacia de Polícia Civil ${ }^{56}$, do Município de São Geraldo do Araguaia, sob No 2003.000110, em 17 de março de 2003, e enquadrou o fato como roubo simples e tentativa de homicídio ${ }^{57}$.

\footnotetext{
${ }^{53}$ A ocorrência policial foi registrada pela Delegada de Polícia Civil Cláudia Pimentel Ribeiro.

${ }^{54} \mathrm{O}$ inquérito policial é presidido pelo Delegado de Polícia Federal José Antônio da Silva.

${ }^{55}$ Artigos 157, § 2 , I e 129, todos do Código Penal Brasileiro (CPB).

${ }^{56}$ O procedimento foi conduzido pela Delegada de Polícia Cláudia Pimentel Ribeiro.

${ }^{57}$ Artigos 157 e 124 c/c 14, II, todos do CPB.
} 
BELTRÃO, MASTOP-LIMA e MOREIRA - De vítimas a indiciados ...

CRIME DE ROUBO/TENTATIVA DE HOMICÍDIO: O Relator acima identificado comunica que na madrugada do dia de hoje viajava da cidade de Marabá/PA para Araguaina/TO, onde sua esposa Juliana Ferreira Pagane, iria submeter-se a alguns exames médicos, porém ao passarem em frente a ALDEIA INDÍGENA SURUÍ SORORO, foram surpreendidos pela presença de vários homens, todos armados com ESPINGARDAS, os quais estavam posicionados a margem da RODOVIA BR-153, momento em que o relator percebeu a existência de uma barricada, a qual obstruía a passagem de veículos; QUE acreditando tratar-se de um assalto, o relator passou pela barricada, sendo então alvo de vários disparos de ESPINGARDAS, que lhe perfuraram o veículo, os quais foram efetuados pelos homens que estavam a margem da estrada - que somente depois, o relator soube tratar-se de índios da aldeia SURUI SORORO - momento em que seguiu viagem, porém, cerca de 5 (cinco) Kms, a frente, foi surpreendido por uma segunda barricada, que era reforçada por um grande aglomerado de ÍNDIOS, todos da aldeia SURUI SORORO; que o relator e sua esposa JULIANA foram retirados de dentro do veículo (CAMINHONETE, marca GMC, modelo 6100,cor VERMELHA, placa KEI-6935, ano de fabricação e modelo 2001/2001, categoria ALUGUEL), e passaram a ser espancados pelos ÍNDIOS, que os levaram para o interior da aldeia SURUI SORORO, onde roubaram-lhe a soma de $\mathrm{R} \$ 2.300,00$ (dois mil e trezentos reais) em espécie, além de subtraírem-lhe UMA BOLSA DE VIAGEM com várias peças de roupas do relator e sua esposa; UMA AGENDA TELEFÔNICA; 15 (quinze) fitas $\mathrm{K} 7$ e muitos outros objetos pessoais; que os índios também subtraíram-lhe quase todo o combustível do tanque do veículo; que o relator e sua esposa apesar de estarem em tratamento médico e de suplicarem aos seus agressores, foram torturados por cerca de 7 (sete) horas e só foram liberados por volta das 12:30 horas, após a chegada de vários funcionários da FUNAI, os solicitaram que os índios os liberassem; que ouviu os índios chamarem um de seus agressores, uma mulher, pelo nome de TERI, outro que era chamado por CACIQUE, sendo este que liderava as agressões e o saque dos bens roubados. Registra-se para ulteriores de direito (Boletim de Ocorrência Policial No 2003.000110 lavrado em 17 de março de 2003 - grifos no original).

Espaço Ameríndio, Porto Alegre, v. 2, n. 2, p. 194-258, jul./dez. 2008. 
BELTRÃO, MASTOP-LIMA e MOREIRA - De vítimas a indiciados ...

Na seqüência, houve declarações prestadas junto à Administração Executiva da Funai/Marabá, transcrita no Inquérito da seguinte forma:

[a]os vinte e um de Março, de 2003, compareceram a sede da FUNAI - Administração Executiva Regional de Marabá, situada à Folha 31, Quadra 01, Lotes 01 e 02, nesta cidade de Marabá, Estado do Pará, o Senhor DIVINO ETERNO DA SILVA, brasileiro solteiro, CPF n.o 489.122.202-68, RG n.0 310.526-8, SSP/PA, residente e domiciliado na Avenida Principal, no 37, Vila Gravatá, no município de Eldorado dos Carajás, Estado do Pará, e a Senhora. JULIANA FERREIRA PAGANI, brasileira, solteira, CPF no 629.669.872-00, R.G. no 339.515-6 SSP/PA residente e domiciliada no mesmo endereço acima mencionado, e prestaram as seguintes declarações: QUE no dia $17 / 03 / 2003$, por volta de 04:00 horas, deslocaram-se de Marabá através do seu veículo caminhão GMC 6-100, cor vermelha, de placa KEI-6935, com destino à cidade de Araguaína-TO; QUE ao se aproximarem da área dos índios Suruí, foi surpreendido com paus na rodovia BR-153, e vários homens armados; QUE pensaram que se tratava de um assalto; QUE o condutor do veículo, o Sr. Divino, conseguiu transpor os obstáculos; QUE ouviram alguns disparos de arma de fogo contra o veículo; QUE os tiros atingiram o veículo e o condutor; QUE logo adiante havia outra barreira; QUE nesta o condutor foi obrigado a interromper a viagem; QUE nesse momento, conheceram que se tratava de índios interditando a rodovia; QUE nesse momento, o condutor, ao perceber que não se tratava de assalto, sentiu uma sensação de alívio, pois nunca esperava atitudes covardes por parte dos índios; QUE os índios apontaram arma de fogo contra 0 declarante $e$ começaram a espancar o declarante; QUE os índios torturam bastante o declarante e sua companheira; QUE entre índios que os torturam destacaram-se três: UMASSU, TERI e ALEX; que esse movimento contra os declarantes teve início por volta das 05:00 horas; QUE os declarantes ficaram em poder dos índios até por volta de 12:30 horas; QUE os declarantes somente foram liberados após a chegada do pessoal da FUNAI no local; QUE ao retornarem para o caminhão, os declarantes perceberam que haviam sido roubados; QUE os índios apanharam, do interior do veículo, $R \$ 2.300,00$ e uma bolsa de viagem tipo mochila; QUE na bolsa havia várias

Espaço Ameríndio, Porto Alegre, v. 2, n. 2, p. 194-258, jul./dez. 2008. 
BELTRÃO, MASTOP-LIMA e MOREIRA - De vítimas a indiciados ...

roupas e objetos pessoais, como fita cassete, produtos de higienização e limpeza, etc.; QUE os índios apanharam também uma sacola de ferramentas e retiraram aproximadamente 80 litros de óleo diesel do tanque do caminhão; QUE os declarantes registraram a ocorrência na Delegacia da Polícia Civil em São Geraldo; QUE os declarantes foram submetidos a exame de corpo de delito, no Instituto de Pesquisa Científicas Renato Chaves, em Marabá. QUE os declarantes esperam que sejam tomadas as devidas providências por parte das autoridades competentes (Inquérito 146/03 DPF. B/MBA/PA - grifos no original).

E assim foi instaurado o inquérito policial com o objetivo de apurar a responsabilidade penal dos Suruí Aikewára, da Área Indígena Sororó. O inquérito passou à esfera da Polícia Federal por intervenção da Procuradora da República em Marabá, Eloísa Helena Machado ${ }^{58}$.

A versão de Divino Eterno da Silva está posta no Boletim de Ocorrência produzido a partir da Delegacia de Polícia em São Geraldo do Araguaia e nos autos do Inquérito instaurado pela Polícia Federal em Marabá.

A voz dos Suruí Aikewára não é registrada no Inquérito, pelo menos até 5 de junho de 2003. Assim sendo, cabe ao Laudo Antropológico apresentar a versão dos Suruí Aikewára, até porque pelo fato de não terem se dirigido, eles próprios, ou os representantes da agência tutelar para fazer o registro da agressão, tornaram-se indiciados.

Mas para esclarecer o conflito, é necessário contextualizar as ocorrências, pois as ações indígenas estão fortemente vinculadas à compreensão de mundo e da sensibilidade jurídica dos Suruí Aikewára.

\section{Um corpo produz revolta}

Em 16 de março de 2003, por volta das 17 h, o Suruí conhecido como Jurandir retornava à aldeia Sororó, após a ida ao castanhal, quando os índios aproveitam a oportunidade para caçar, quando encontrou o cadáver

\footnotetext{
${ }^{58}$ Cf. OFÍCIO PRM/MAB/GAB/No371/2003 de 23 de abril de 2003.
} 
BELTRÃO, MASTOP-LIMA e MOREIRA - De vítimas a indiciados ...

de um desconhecido à margem esquerda ${ }^{59}$ da BR-153, mais ou menos na metade do corte produzido pela rodovia na área indígena, à altura do local chamado por eles de Cupu, distante cerca de $8 \mathrm{~km}$ da entrada da aldeia, onde estão situados alguns castanhais e onde costumam pescar, portanto em terras pertencentes aos Suruí Aikewára.

O corpo estava escondido em meio à mata marginal (Fotos 9 e 10) despido e em adiantado estado de decomposição. Assustado, Jurandir retornou à aldeia e relatou a ocorrência aos demais membros da comunidade. Ocasião em que Mairá, o líder dos Suruí Aikewára ${ }^{60}$, acompanhado de outros índios e de Mário Pereira ${ }^{61}$ foram até o local para verificar o episódio relatado.

Ao chegarem ao referido local, por já estar escuro, e temerem corpos não enterrados, os índios solicitaram a Mário que fosse olhar o cadáver. $O$ mesmo, utilizando uma lanterna, observou tratar-se de um corpo do sexo masculino, já em estado de decomposição.

\footnotetext{
${ }^{59}$ No sentido São Domingos/São Geraldo do Araguaia.

${ }^{60}$ Denominado e reconhecido por índios e não índios como cacique, chefe temporal, filho de Sawarapí Suruí, morto, em 1984, em acidente de trânsito. O termo adequado à chefia temporal em se tratando de povo Tupi, como comentou Roque Laraia em uma de nossas discussões, seria morubixaba ou maurobixawa como ouvido por ele na década de 60. Outras variantes também são admitidas: murubixaba, morubixába, morubuxaba, morubixawa, murumuxaua, muruxaua, tubixaba, tubixacatu, tubixacatû, tuxaua e curaçá. Moru indica qualquer principal, capitão; e tubixaba indica quem ou aquele que tem mando. Há referências ao termo desde 1584 em trabalhos de missionários e viajantes. O termo cacique foi consagrado, chama-se também capitão, denominação cunhada desde o antigo Serviço de Proteção aos Índios (SPI), agência tutelar que precedeu a FUNAI. Sobre o assunto e as referências à literatura, consultar Cunha (1989). .

${ }^{61}$ Mário Pereira é engenheiro florestal e participa há seis meses de projeto desenvolvido na aldeia. $\mathrm{O}$ depoimento do profissional foi concedido através de entrevista, concedida em 14.06.2003, em Belém.
}

Espaço Ameríndio, Porto Alegre, v. 2, n. 2, p. 194-258, jul./dez. 2008. 
BELTRÃO, MASTOP-LIMA e MOREIRA - De vítimas a indiciados ...

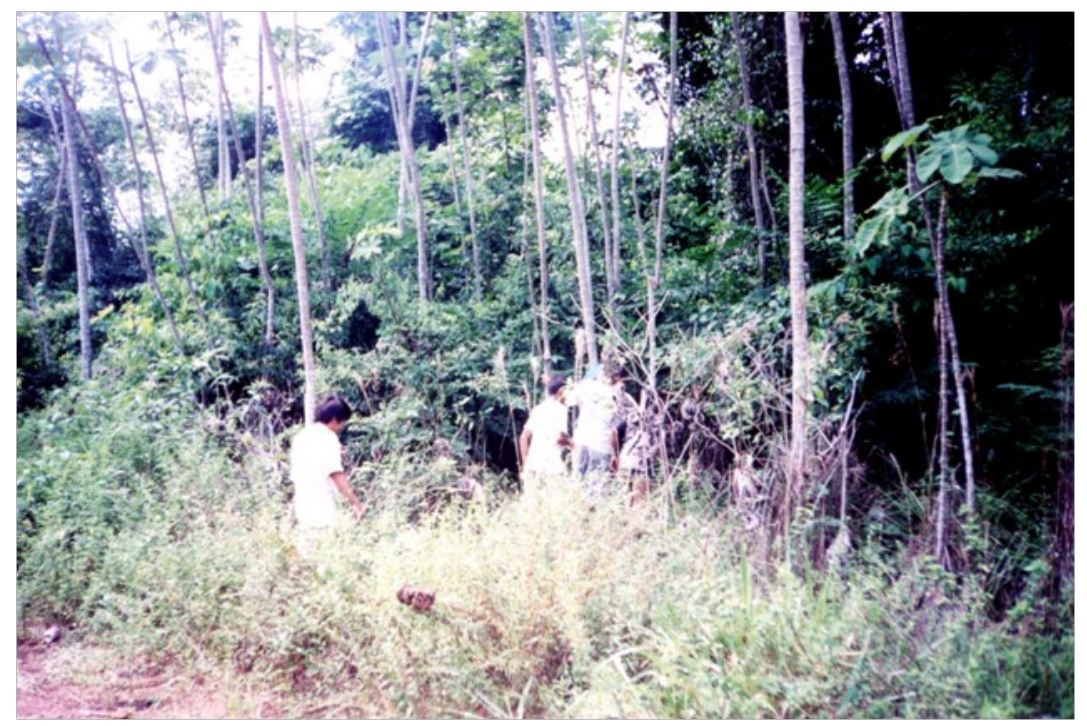

Foto 9

Em seguida, o cacique retornou à aldeia e imediatamente comunicou o ocorrido à FUNAI em Marabá, através do rádio, para providenciar a retirada do cadáver e evitar transtornos aos membros da comunidade. Todavia, paralelamente, em reunião realizada na própria estrada, às adjacências do local onde foi encontrado o cadáver, os membros da aldeia decidiram conjuntamente produzir o "entupidimento" 62 da rodovia, ocupando as duas extremidades das terras pertencentes ao território que Ihes é legalmente reconhecido.

$\mathrm{Na}$ extremidade chamada de Gameleira, próximo aos limites do município de São Geraldo do Araguaia, além das "galhadas", os índios contaram com a colaboração dos caminhoneiros que compreenderam e aderiram à manifestação, colocando caminhões para ajudar a "entupidinir" a ponte sobre o rio Gameleira.

Às proximidades da aldeia, o "entupidimento" da rodovia foi realizado com troncos e galhos de árvores, dispostos na estrada (Fotos 11

\footnotetext{
${ }^{62}$ Expressão utilizada pelos Suruí Aikewára para designar a obstrução da BR-153. Ao produzir o "entupidimento" (que pode ser traduzido como um entupimento que ocasiona impedimento) os membros da comunidade reúnem troncos, galhos e toda sorte de madeira que possa se constituir em obstáculo, ao obstáculo em si, os Suruí denominam "galhadas".
}

Espaço Ameríndio, Porto Alegre, v. 2, n. 2, p. 194-258, jul./dez. 2008. 
e 12). Nessa extremidade, participavam da ação em sua maioria jovens na faixa de 16 a 24 anos (ver ilustração em anexo).

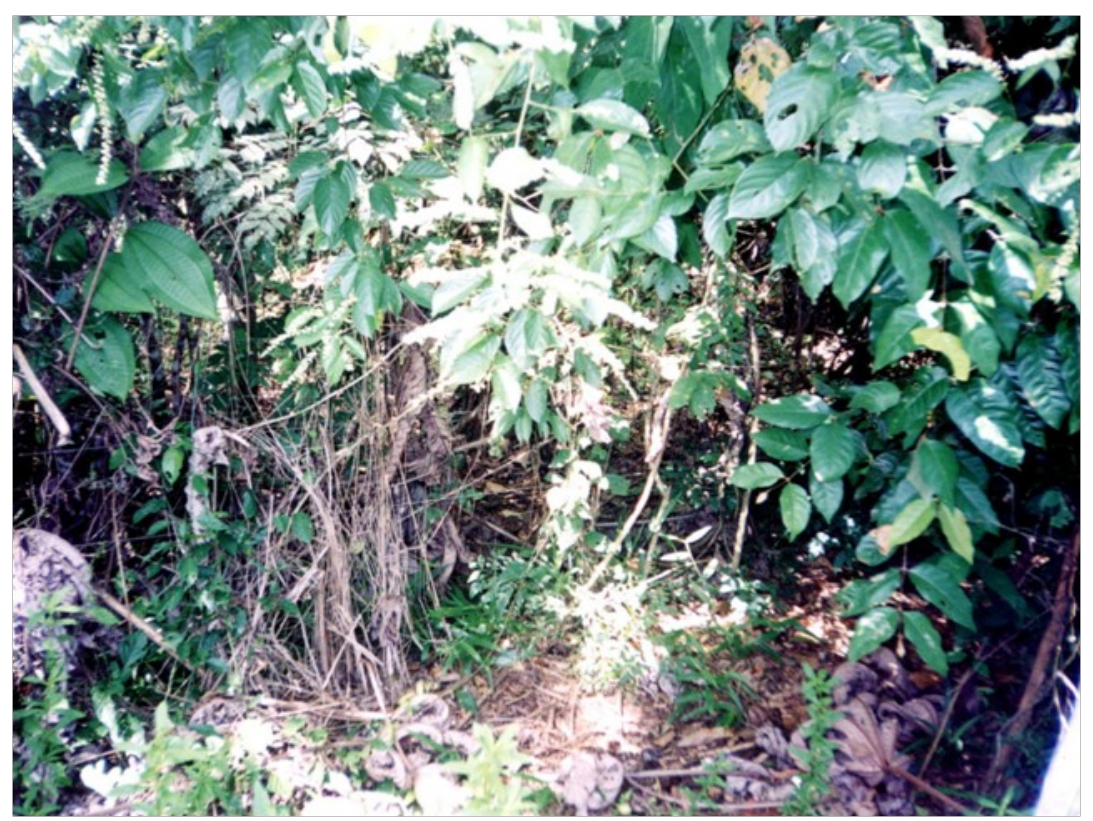

Foto 10

O "entupidimento" da estrada não foi realizado de forma absoluta. Quando os carros se aproximavam, os indígenas sinalizavam, explicavam aos motoristas as razões da ação e os mesmos retornavam para a localidade denominada Some $\mathrm{Home}^{63}$. Todavia, quando constatada a necessidade, como ocorreu em três casos, os carros eram autorizados a passar, a exemplo de uma ambulância que se dirigia para São Geraldo transportando um paciente e dois outros carros, entre eles um Fiat, em cujo interior viajava uma pessoa com saúde debilitada.

Em decorrência da difusão da notícia do "entupidimento" da rodovia entre os motoristas reunidos em Some Home, os carros começaram a se concentrar nessa localidade e não seguiam viagem.

\footnotetext{
${ }^{63}$ Segundo relatos coletados em campo, em junho de 2003, os motoristas ficaram concentrados no Some Home aguardando a liberação da rodovia e informavam aos demais sobre o assunto. Assim, os condutores desistiam de prosseguir no caminho. Divino Eterno foi informado das ocorrências, pelos companheiros de profissão, mas sua conduta foi intempestiva.
}

Espaço Ameríndio, Porto Alegre, v. 2, n. 2, p. 194-258, jul./dez. 2008. 
BELTRÃO, MASTOP-LIMA e MOREIRA - De vítimas a indiciados ...

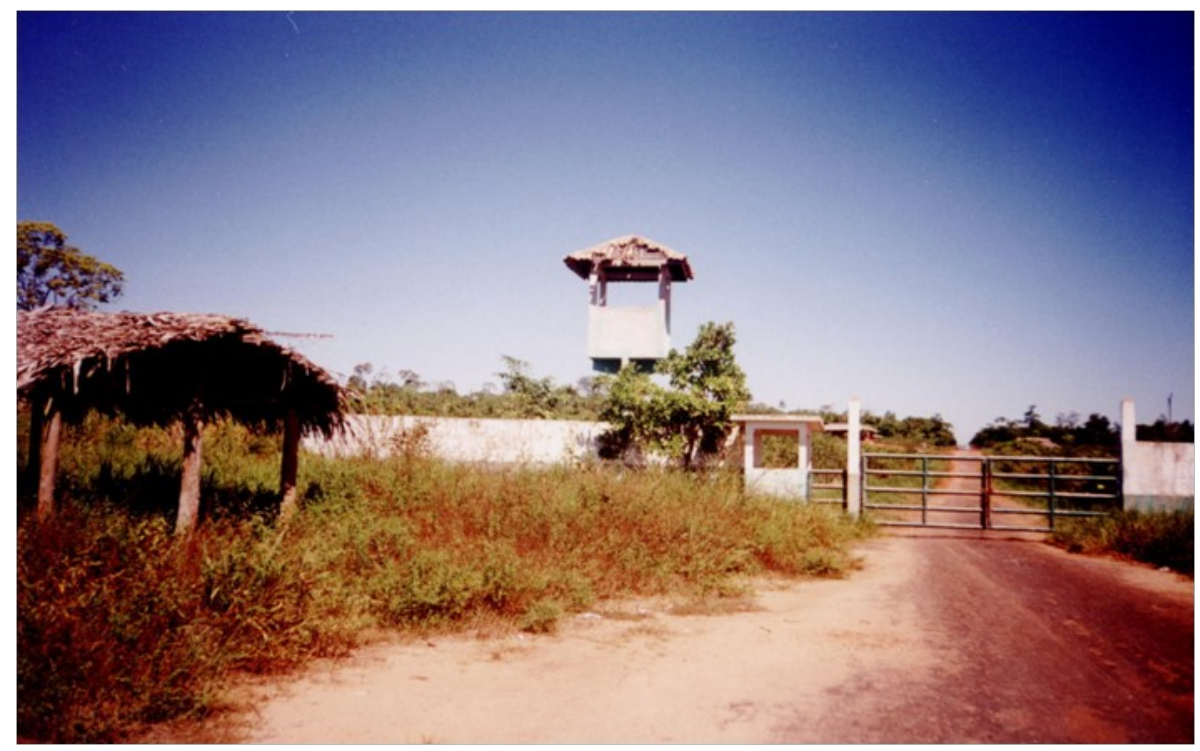

Foto 11

Assim, por volta das vinte e três horas do dia 16 de março de 2003, o tráfego de veículos leves e pesados na rodovia foi reduzido a zero.

Por volta das seis horas da manhã do dia seguinte, os Suruí se encontravam na estrada quando o caminhão placa: KEI 6935, conduzido por Divino Eterno da Silva se aproximou e, mesmo ante a sinalização para que parasse, em alta velocidade avançou por sobre a "galhada" à altura do portão da entrada da aldeia, quase atropelando quatro dos índios que guarneciam o "entupidimento", que "pularam como goleiros" na rodovia para não serem atropelados, sofrendo ferimentos nos cotovelos e joelhos. Informa uma das vítimas:

... meu irmão disse que deu um sinal pra ele, né, deu sinal com a lanterna, pra ele, ele piscou três vezes a lanterna dele lá, aí disse que ele ... de longe ele vinha matando a carreira, aí disse que quando ele chega mais pra cá um pouquinho, quando o meu irmão foi lá pra conversar com ele, aí disse que ele ... na hora que ele foi chegando quase lá, disse que ele acelerou o carro e passou por cima dos paus, aí que o meu irmão também pulou fora da estrada lá. E os outros que tava lá pertinho dos paus, lá na barreira lá, aí disse que pulou tudinho no. mato, se não tivesse pulado nenhum, ele tinha passado. 
BELTRÃO, MASTOP-LIMA e MOREIRA - De vítimas a indiciados ...

por riba, lá, ... (Entrevista com Suruí, 19/06/2003 - grifos nossos) ${ }^{64}$.

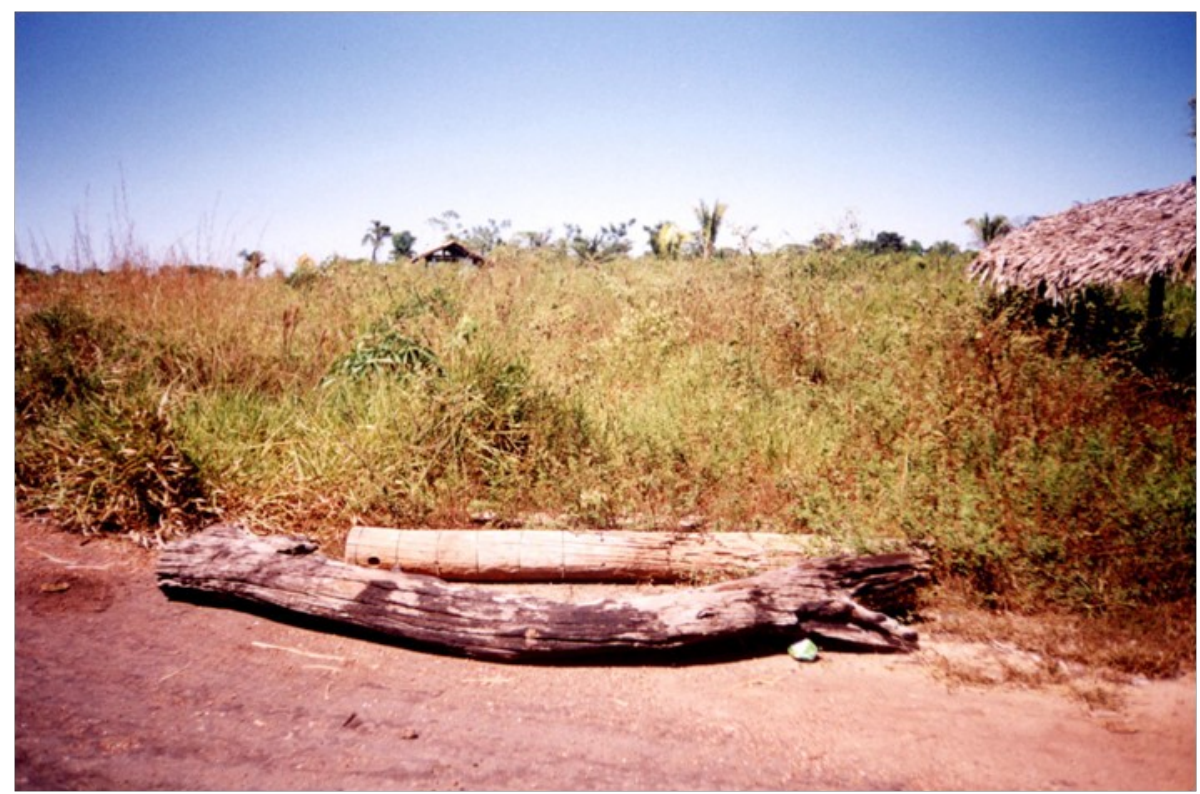

Foto 12

Narram os membros da comunidade que o caminhão quase vira, mas não parou, continuou avançando em direção aos membros da comunidade, ocasião em que um dos integrantes da área conflagrada fez disparos de advertência ${ }^{65}$ e contra a lateral do caminhão, posto que o motorista não atendia os sinais de parar. Como informam os Suruí:

\begin{abstract}
aí os pessoal também não gostaram né, aí os pessoal também não gostaram, aí atirou, e aí atirou no caminhão dele, tá, e quebrou o pára-brisa do carro todo, ... Até os caminhonero falou lá né, no caminho: "ei, o quê que aquele homem que vocês pegaram ... o que é que ele fez?" "mas rapaz ele passou lá na barreira lá, lá também,
\end{abstract}

\footnotetext{
${ }^{64}$ Depoimento de Tatawirá, durante a entrevista coletiva concedida pelos Suruí Aikewára, em 19.06.2003, na aldeia. Filho de Tibakú e Terí, é um jovem recatado e tímido, pouco fala. Cremos que se manifestou durante entrevista coletiva para reforçar os depoimentos de Tymykong e Tawé, além de sair em defesa do irmão dele, Arakapitã, um dos jovens quase atropelados por Divino Eterno, e da mãe, Terí, que foi acusada pelo caminhoneiro na queixa prestada na Delegacia de Polícia em São Geraldo do Araguaia.

${ }^{65}$ Os índios que guarneciam o "entupidimento" nesse trecho da estrada eram em sua maioria jovens e estavam desarmados. Todavia, alguém não identificado, portando cartucheira usada para caça de animais, ao perceber o perigo, o desrespeito à barreira e o risco à vida dos demais, disparou um tiro de advertência e um outro que atingiu a lateral do caminhão.
}

Espaço Ameríndio, Porto Alegre, v. 2, n. 2, p. 194-258, jul./dez. 2008. 
BELTRÃO, MASTOP-LIMA e MOREIRA - De vítimas a indiciados ...

que ele nem respeitou lá" "rapaz se ... ele é doido né, ele não pode fazer isso não, que aqui é reserva de vocês, aqui tem ... todo mundo tem que respeitar". Aí né, aí quando ele falou pra nós: "ah, eu pensei que era bandido" aí na hora que ele vem daqui né, ... (Entrevista com Suruí, 20/06/2003 - grifos nossos).

$\mathrm{Na}$ lógica Suruí as terras e os membros da comunidade, especialmente jovens, devem ser defendidos diuturnamente, invadir o território e agredir os membros da comunidade são faltas gravíssimas na sensibilidade jurídica Aikewára.

Transposta a "galhada", Divino Eterno percorreu cerca de $9 \mathrm{~km}$ nas terras indígenas, em alta velocidade, mas não teve como ultrapassar a ponte sobre o rio Gameleira, pois, além da "galhada" havia carretas obstruindo a rodovia.

Ao chegar nesse limite, Divino Eterno que se fazia acompanhar de Juliana Ferreira Pagani ${ }^{66}$ desceu do carro, ocasião em que informou ter ultrapassado a barreira por estar dirigindo a $120 \mathrm{~km} / \mathrm{h}$, o freio estar danificado e sua mulher estar passando mal. Insatisfeitos com a desculpa, os Suruí integrantes da barreira resolveram deter Divino Eterno e esperar o "povo" chegar para esclarecer os fatos. Quotidianamente e em momento de crise e/ou conflito as ações Suruí são fruto de deliberação coletiva, daí porque se fez necessário esperar o "povo" chegar, pelas normas vigentes não se age individualmente.

Segundo Tymykong ${ }^{67}$ :

Mas ele que foi culpado, porque ele veio com falta de respeito, porque ele não teve paciência aí como ... a ambulância parou lá e falou assim: "ô... meu amigo índio eu posso passar que aqui tem um paciente passano mal", aí o pessoal empurrava o pauzão assim que tava no meio, aí ele passava. E ele, porque não pediu também. Ele disse

\footnotetext{
${ }^{66}$ Divino alegou que Juliana era sua esposa. Todavia, os relatos coletados não comprovam o fato.

${ }^{67}$ Filha de Muretama e Awasaí, pajé entre os Suruí Aikewára, foi professora na aldeia e, entre as mulheres casadas que ainda não são guerreiras (classe de idade, atingida entre 45 e 50 anos), destaca-se pela força com que reivindica seus direitos e dos demais Aikewára; por diversas vezes, representou os Suruí em eventos organizados por entidades que trabalham com os índios, como o Conselho Indigenista Missionário (CIMI), por exemplo. Na reunião realizada em 19. 06. 2003 Tymykong, destacada pelo cacique Mairá para relatar os fatos ocorridos em 17 de março de 2003, falou em primeiro lugar e foi apoiada e endossada pelos presentes à reunião.
}

Espaço Ameríndio, Porto Alegre, v. 2, n. 2, p. 194-258, jul./dez. 2008. 
BELTRÃO, MASTOP-LIMA e MOREIRA - De vítimas a indiciados ...

que tava com essa mulhezinha doente aí passou. Não é por causa que essa mulher tava passano mal. E porquê que ele não pediu que nem os outro pediram? Pois é (Entrevista com Suruí, 19/06/2003 - grifos nossos).

Tymykong estava apontando uma diferença entre os kamará (brancos). Há kamará que repeita os índios e se refere a eles como "meu amigo índio", no caso de Divino Eterno o respeito foi esquecido.

Ao saber que um carro havia transposto à força a "galhada" disposta na rodovia, Mairá, o cacique da aldeia, se fez acompanhar de outros membros da comunidade e de Mário Pereira que dirigiu o carro da aldeia até a ponte do rio Gameleira, onde possivelmente estaria retido o veículo.

Ao chegarem ao local, observaram que o motorista e sua companheira estavam detidos para serem conduzidos à guarita da entrada da aldeia.

Nessa ocasião foi permitido a Divino Eterno estabelecer comunicação, através do rádio de um dos caminhões que obstruía a rodovia. Todavia, em sua comunicação o mesmo fez comentários considerados ofensivos pelos índios ${ }^{68}$, que decidiram suspender o contato, dado o desrespeito.

Em seguida, o caminhão, Divino Eterno e Juliana Pagani foram conduzidos à aldeia, ficando ele ao lado da guarita localizada à entrada, ocasião em que as mães dos jovens que quase foram atropelados ao guarnecerem o "entupidimento" da estrada, sofrendo lesões corporais, por "pularem como goleiros" para não serem apanhados e mortos, passaramIhe a paxiba ${ }^{69}$ em rosto, pois com sua conduta, transgrediu normas socialmente instituídas entre os Suruí Aikewára, sendo considerado kamará punura.

São uníssonas as declarações que, somente as mulheres, mães que diante possibilidade de terem visto seus filhos mortos, por desrespeito a

\footnotetext{
${ }^{68}$ Diversos foram os relatos confirmando que Divino teria dito estar "preso no meio da selva amazônica, por índios selvagens, bandidos (...)" e adjetivos congêneres, bem como que "odeia índios".

${ }^{69}$ Raízes aéreas de palmeira denominada Paxiúba (Iriartea exorriza) que de tão ásperas e duras são usadas para ralar castanha e coco. "Passar a paxiba" no corpo de um transgressor tem como finalidade marcá-lo para que não esqueça do ato de violar regras socialmente estabelecidas.
}

Espaço Ameríndio, Porto Alegre, v. 2, n. 2, p. 194-258, jul./dez. 2008. 
BELTRÃO, MASTOP-LIMA e MOREIRA - De vítimas a indiciados ...

uma decisão coletiva, passaram a paxiba em Divino Eterno. Como informa Tatawirá:

aí nós dexemo ele lá. Preso aí. Aí quando ... Aí o pessoal ... quando ele chegou aqui né. Nós pedimo lá, nós fomo, nós tava lá né, "ó, né pra vocês fica judiando muito dele lá não, porque ele não machucou nenhum de nós né, agora, se nós mata ele aqui, aí nós perdi os direito nosso, nós perdi nosso direito". Aí o pessoal: "então tá bom". Aí ele chegou aqui né, dizem que ele falou meio mundo de besteira pro pessoal, falou que não gostava de índio, aí os pessoal nosso, não gostaram né, aí pegaram a paxiba e passaram na cara dele. Aí foi só isso também (Entrevista com Suruí, 19/06/2003 - grifos nossos).

Diferentemente, Juliana Pagani foi conduzida à casa da vigilância, ao lado da qual foi estacionado o caminhão de Divino, sem sofrer qualquer tipo de sanção.

Segundo o depoimento de Mário Pereira, confirmado por diversos outros depoimentos, Juliana declarou que ao chegarem à comunidade de Some Home foram informados que a rodovia estava obstruída, mas que se fosse urgente poderia falar com os índios que eles liberariam, visto não terem a "fama" de violentos. Nessa ocasião, os caminhoneiros avisaram a Divino que não deveria passar, mas Divino teria retrucado afirmando que iria passar ${ }^{70}$. Tatawirá relatou indignado que o caminhoneiro teria dito aos demais: "ah, rapa vocês não passa porque vocês são tudo frouxo parece, mas eu passo lá, quer ver eu passar agorinha também lá?" E Tatawirá conclui "... ele é atrevido queria passar!"

O veículo de Divino ficou estacionado à entrada da aldeia, tendo sido vistoriado pelos índios para verificar se havia armas no porta-luvas, ocasião em que descobriram que o proprietário possuía duas carteiras de identidades com nomes distintos e fotografias diversas para documentos com roupas variadas, dois registros de contribuinte (CIC), fato levado ao conhecimento de Mário Pereira e repassado aos representantes da FUNAI,

\footnotetext{
${ }^{70}$ Segundo alguns depoimentos, Divino Eterno, em seus arroubos de macho teria usado palavras de baixo calão, fato que deixou os Suruí estarrecidos e indignados. Para confirmar sua valentia e seu atrevimento, declarou ser "escroto".
}

Espaço Ameríndio, Porto Alegre, v. 2, n. 2, p. 194-258, jul./dez. 2008. 
BELTRÃO, MASTOP-LIMA e MOREIRA - De vítimas a indiciados ...

com a sugestão dos Suruí, não observada pelos representantes da Funai, de aguardar a chegada da polícia.

Uníssonas são as declarações que não foi subtraída qualquer quantia em dinheiro de Divino e que os cheques existentes entre seus pertences Ihes foram devolvidos juntamente com a documentação.

$\mathrm{Na}$ condição de antropóloga, diz Beltrão, que trabalha com os Suruí, desde 1998:

em diversas ocasiões pude observar a honestidade dos membros da comunidade. Em uma das muitas audiências $^{71}$ às quais os Suruí Aikewára precisavam se fazer presentes, enviei quantia em dinheiro à aldeia, através do Sindicato dos Trabalhadores Rurais de São Domingos do Araguaia. E a quantia, destinada ao transporte dos representantes do grupo, não foi utilizada. O dinheiro me foi devolvido por Mahú Suruí, assim que chegou à reunião, pois tinha pego "carona" no caminhão da FUNAI que foi à aldeia pegar castanha. Destaco que, nas circunstâncias, eu jamais teria conhecimento do fato se ele não tivesse devolvido a quantia e oferecido as explicações pertinentes. O repasse ao qual me refiro foi feito, entre contas correntes (minha conta pessoal e a do Sindicato acima referido), via Branco do Brasil, documento 0565-7, em 27 de julho de 1998, quando eu recém conhecera os Suruí Aikewára. Guardei o documento em meu caderno de campo por ter ficado emocionada com o gesto, especialmente sabendo que no verão paraense os Suruí pouco têm para comer, dada a seca dos cursos d'água em suas terras (Notas de campo, julho de 1998$)^{72}$.

Voltando aos acontecimentos, por volta das $11 \mathrm{~h} 40$, ainda no dia 17 de março de 2003, chegaram à aldeia os representantes da FUNAI, senhores Carlos Loureiro, engenheiro agrônomo e Tibério, chefe de posto, e outro funcionário, que os índios referem como Brasil, "desrespeitando" Mairá e os demais membros da comunidade determinaram a liberação

\footnotetext{
${ }^{71}$ É provável que o registro da cena tenha sido feita por Haraxare Krokti Ronore Konxarti, Gavião Parkatêjê, conhecido como Matias, que filmou a audiência presidida pela $\operatorname{Dr}^{\mathrm{a}}$ Neide M. C. Cardoso de Oliveira, Procuradora da República em Marabá em 1998, posto que na condição de documentarista Haraxare é atento e arguto na condição de "olhos e ouvidos" daqueles que não se fizeram presentes à audiência.

${ }^{72}$ Notas de campo, datadas de julho de 1998, quando se negociavam as perdas Suruí Aikewára e a elaboração do Laudo de 1998, anteriormente referido.
}

Espaço Ameríndio, Porto Alegre, v. 2, n. 2, p. 194-258, jul./dez. 2008. 
BELTRÃO, MASTOP-LIMA e MOREIRA - De vítimas a indiciados ...

imediata de Divino Eterno e Juliana Pagani, o que foi feito. Ato intempestivo, pois como repetem em coro indignado os Suruí: "por que não esperaram a polícia?" Os membros da comunidade, à época da coleta de dados, ainda estavam profundamente magoados com a FUNAl e seus agentes.

No mesmo dia, segundo os Suruí, por volta das $21 \mathrm{~h}$, o administrador executivo regional da FUNAl, em Marabá, senhor Eimar Araújo "desentupidiu" a estrada solicitando aos caminhoneiros usar terçados, facões e até motosserra. E assim se dirigiu à aldeia acordando os índios aos gritos, provocando revolta entre os mesmos, aumentando o clima de tensão. Segundo declarações dos índios, após aquele dia, o administrador da FUNAl tornou-se pessoa indesejada na aldeia e até final do mês de junho não mais havia retornado. Com disse Mahú ${ }^{33}$ : "por que ele gritou? Pode ser amigo, mas não podia fazer nada sem ouvir nós".

Tawé $^{74}$ ao se pronunciar sobre o desrespeito dos funcionários da FUNAl ao soltarem os kamará punura, "desentupidinirem" a rodovia, gritar à noite com suas autoridades indica o procedimento que deveria ter sido adotado. Reproduz-se a seguir parte da entrevista coletiva realizada em 19 de junho de 2003:

Tawé - Antes disso quando eles encontraram o cadáver pra lá, nós pedimo duas vezes, pra FUNAI, mandar vir pra fazer, trazer algum da polícia, vim reparar o cadáver né, aí nenhum deu a resposta pra nós, aí ficou...

Jane - Foi pelo rádio?

Tawé - Foi pelo rádio... Aí eles falaram: "não tamo de férias, não pode ser, que num sei o que lá, só na reunião, num sei o que" então nós fiquemo dois dias esperano eles. Aí por causa desse daí, eles fizeram três dias, já que num veio também, por três dias. Aí que nós começamos a botar os paus. Foi assim que aconteceu né, por que nenhum, nem policial não respondeu, nem delegacia,

\footnotetext{
${ }^{73}$ Irmão de Mairá, ambos filhos de Sawarapí Suruí é o segundo cacique, como eles dizem; na ausência ou mesmo na presença de Mairá, Mahú sistematicamente se manifesta e a comunidade cobra isso dele, especialmente, pela firmeza de suas posições em defesa dos direitos dos Suruí Aikewára.

${ }^{74}$ Responsável pela vigilância da entrada da aldeia, onde mora numa casa com a família. Quando chega alguém à aldeia é primeiro a ele que se dirige, Mairá e a comunidade lhe dão o poder de fazer alguém voltar do portão da entrada, se for o caso. Ele é, portanto, uma pessoa treinada para negociar, por isso o depoimento dele a respeito de como deve proceder uma pessoa é dado com autoridade. Ao se pronunciar, Tawé teve apoio de vários dos presentes à reunião de 19 de junho de 2003.
}

Espaço Ameríndio, Porto Alegre, v. 2, n. 2, p. 194-258, jul./dez. 2008. 
BELTRÃO, MASTOP-LIMA e MOREIRA - De vítimas a indiciados ...

nem... nem polícia. Nenhuma não atendeu não. Foi por isso que nós coloquemo lá os paus na estrada, pra vê se eles vinha atender mais rápido e não veio. Aí depois que fizeram. Isso aconteceu com esse homem, o caminhonero que passou aí. Foi depois disso que eles vieram. Pediram até desculpa. "Não, não foi, não foi por que nós não quisemo não, foi por que a gente tava tudo ocupado, não sei o que". Aí mais, ficou mais uns dias ainda pra vim as pessoa que pega o corpo né, ficou mais uns dias ainda.

Jane - E eles vieram pegar o corpo?

Tymykong - Vieram.

Tawé - Veio já com cinco dias. Pegar ... (Entrevista com Suruí, 19/06/2003 - grifos nossos).

A veemência dos depoimentos vem sob forma de lamento. A ladainha é antiga e a falta de sensibilidade parece flagrante, os Suruí são delicados ao queixar-se, mas argutos observadores, clamam seus direitos, especialmente quando acreditam que têm razão.

São os depoentes que prosseguem dizendo que quando $o$ administrador da FUNAI chegou, como informa Tawé:

... tinha muito caminhonero né, e nós tava lá na hora, aí lá conversou com o caminhonero lá que podia, que nós fizemo lá né, "não, não, vocês tem machado ou motoserra pode fazer na minha conta" ... falou pra ele, eu ouvi tudo que ele falou. Eu acho que ele tava com um ferro que se chama pé de bode né, e rebentou o cadeado. Aí já entrou comigo lá, já me gritando também. Por que que nós fizemo aquilo lá? Eu falei pra ele, rapaz nós ... Tu devia chegá aqui pra conversar direitinho primero, e nós ia explicar, nós ia conversar direitinho como foi que aconteceu também, mas ele não deixou não. Aí depois eles pegaram esses dois aqui, mais o marido dela aí, e trouxeram ele pra cá. De lá mesmo já vinha acordando todo mundo aí, já fora de hora.

Jane - Acordando como? Ele buzinou?

Tawé - Acho que gritando aí. Chamando os outro aí. Por aí assim. Eu não tava aqui não, eu tava lá no gurita.

Jane - Eles costumam fazer isso?

Homem - Não.

Tawé - Não, eles não costumam não.

Tawé - Ele tava muito nervoso.

Um dos homens - Ele tava nervoso aí.

Vários falam - Ele tava zangado

Espaço Ameríndio, Porto Alegre, v. 2, n. 2, p. 194-258, jul./dez. 2008. 
BELTRÃO, MASTOP-LIMA e MOREIRA - De vítimas a indiciados ...

Tawé - Foi assim que aconteceu

Jane - Vocês já conversaram com ele depois disso?

Vários falam - Não (Entrevista com Suruí, 19/06/2003 grifos nossos).

Mesmo magoados, os Suruí contextualizam as ocorrências. Mas observam, incansavelmente, as normas sociais Aikewára.

Para compreender a ação dos índios, em face ao transtorno produzido pelo corpo despejado na AIS, e o entrevero com as autoridades que representavam a FUNAl é preciso compreender a cultura dos Suruí Aikewára. Observe-se que Eimar Araújo é conhecedor dos transtornos que o rompimento de normas produz, em conversa informal, por telefone, com Jane Felipe Beltrão, logo após o evento, declarou: "perdi a cabeça". Eimar, diferente de outros funcionários da agência tutelar, sempre mereceu referências abonadoras dos índios que o tinham/têm na conta de amigo. É um indigenista preocupado com a crítica situação vivida pelos povos indígenas do Tocantins, em vários momentos foi interlocutor respeitoso, inclusive durante a ação direta promovida pelos Suruí por conta dos desmandos de representantes da ENGEPLAN em 1998.

Luiza Mastop-Lima, em 13 de setembro de 2003, assistiu à leitura, feita por um funcionário da FUNAl, do depoimento dado por Eimar Araújo à Polícia Federal. A leitura foi feita na Casona, na presença e por solicitação do administrador que retornava à aldeia, após os incidentes de 17 de março de 2003. Na ocasião os Suruí, herdeiros da tradição Tupi, comportaram-se como diplomatas de nobre estirpe, ouvindo as histórias e as informações oferecidas pelo representante da FUNAI.

Deixando de lado as desavenças entre os Suruí e Eimar, é preciso responder, por que o corpo transtornou os Suruí Aikewára? Por que o evento parece ter "destampado um caldeirão de descontentamento"? Qual a ligação da ação direta - "entupidimento", obstrução da rodovia - com a saga indígena e a cultura Aikewára?

\section{Crenças e valores Aikewára}


BELTRÃO, MASTOP-LIMA e MOREIRA - De vítimas a indiciados ...

Assim como outros grupos Tupi, os Suruí Aikewára acreditam na sobrevivência da alma. Esta crença foi registrada, ao longo dos anos de contato com a sociedade não-indígena, por antropólogos que trabalharam/trabalham junto ao grupo. Um exemplo disso é o trabalho de Roque Laraia (1986) que, num estudo sobre grupos Tupi, afirma que a crença na sobrevivência da alma, designada pelo termo owera, está relacionada à crença dos Tupi em Mahíra, seu herói civilizador.

Há para os Tupi, segundo Laraia, pelo menos três tipos de espírito: owera, a alma, que sai do corpo enquanto as pessoas dormem; asonga, o espírito dos mortos, que vaga pela terra até que seja chamado ao céu; e os karowara, espíritos especiais, que podem causar doenças e mortes quando descontrolados. Os Suruí Aikewára referem-se aos espíritos dos mortos como asomera, que também vaga pela terra até que se junte no céu aos karuára, espíritos dos pajés que já morreram (MASTOP-LIMA, 2002).

O céu é denominado pelos Suruí, segundo Laraia (1986b), por iwaga. É o lugar onde moram Mahíra e os Karuára, lá há fartura, a plantação não precisa de cuidados para produzir e ela mesma se colhe. É o lugar em que se canta, dança, onde se celebram festas e não se morre ao envelhecer.

Para chegar ao iwaga, o espírito dos mortos precisa percorrer um caminho. Ele deve passar pela itakwára, a morada dos Karuára na terra (LARAIA, 1986b).

É importante conhecer/entender esse aspecto da cosmologia Suruí para que se tenha a possibilidade de perceber, a partir do ponto de vista dos Suruí, o transtorno causado pelo corpo de kamará que foi deixado, abandonado na área que eles habitam.

Os mortos Suruí, assim como em qualquer sociedade, possuem tratamento diferenciado e marcado ritualmente. No dia 19 de junho de 2003, os Suruí enfrentaram a dor de "perder" a pessoa mais antiga entre eles, Wa'a, conhecida e chamada, por todos, Vovozinha.

Para que Vovozinha pudesse completar seu ciclo de vida até ir ter com os Karuára, foram necessários alguns cuidados, apesar da interferência da Igreja Católica. Vovozinha foi acomodada na urna funerária envolta em seus lençóis. Dentro da urna, conforme manda a tradição, 
BELTRÃO, MASTOP-LIMA e MOREIRA - De vítimas a indiciados ...

foram postas suas roupas e seus pertences. Foi ornamentada com tinta de urucu e seu atutú $^{75}$. A pintura facial de Vovozinha foi feita de modo a informar que ela era uma guerreira, uma figura emblemática para os Suruí.

O ritual fúnebre foi marcado por "palavras de despedida", ditas na língua por pessoas mais velhas da aldeia, entre elas uma de suas filhas. 0 cacique Mairá e um dos netos de Wa'a também discursaram, em Português. Algo recorrente em todos os discursos foi o fato de Wa'a ter "morrido de velhice" e que agora ela poderia encontrar-se com os Suruí que já morreram.

Ter "morrido de velhice" é algo importante para os Suruí, pois Vovozinha também representava a vitória dos Suruí contra a ameaça do desaparecimento, de sucumbir perante a sociedade não-indígena. Desaparecimento esse tão iminente na saga do grupo com a situação de contato, que ocasionou muitas perdas, ora designadas por doenças contraídas junto aos brancos, ora por tiros implacáveis disparados por kamará desrespeitosos, ou mesmo pelo envolvimento involuntário na Guerrilha do Araguaia, como se viu anteriormente (BELTRÃO, 1998a).

Para completar seu ciclo de vida, Wa'a teve de ser enterrada. E o foi num cemitério próximo à Aldeia Velha, ao lado de um de seus filhos, Kuimu'a, como ela havia pedido. A partir disso, Wa'a irá ter com os Karuára e poderá chegar ao iwaga.

É importante dizer que sua cova era funda o bastante para que nenhum animal pudesse alcançar seu corpo e dele se alimentar, pois isso seria prejudicial aos Suruí.

Os Suruí Aikewára têm verdadeira repulsa a um corpo em decomposição, seja ele de um ser humano ou de um animal. Isso lhes provoca nojo, sevarú. Muitas vezes testemunhei essa repulsa quando viajava $^{76}$ com eles no carro da aldeia até Marabá ou São Domingos do Araguaia. Se havia animal morto na pista, "automaticamente" eles cuspiam, fechavam as janelas e resmungavam não saber "por que kamará joga bicho na pista".

\footnotetext{
${ }^{75}$ Enfeite de cabeça feito com penas de arara ou tucano dispostas, em tufo sobre a cabeça, e fios de algodão de uso exclusivamente feminino (Mastop-Lima, 2002).

${ }^{76}$ Depoimento de Luiza de Nazaré Mastop-Lima.
}

Espaço Ameríndio, Porto Alegre, v. 2, n. 2, p. 194-258, jul./dez. 2008. 
BELTRÃO, MASTOP-LIMA e MOREIRA - De vítimas a indiciados ...

Para os Suruí Aikewára, um corpo em decomposição é algo impuro. Impuros também e impróprios ao consumo ficam os animais que desse corpo se alimentam, pois se eles consumirem esses animais, ficarão doentes. Procurando evitar as doenças, o lugar onde foi jogado o corpo do kamará, encontrado em 16 de março de 2003, passou a ser interditado para a prática das atividades tradicionais dos Suruí.

Isso é prejudicial para os Suruí tanto cultural como economicamente, uma vez que ali se situam as colocações de castanha de algumas famílias, um dos principais produtos comercializados pelos índios. Além do que, o lugar é uma das referências para a pesca, pois reúne algumas quotas dos escassos recursos hídricos que a eles restou depois da demarcação da Área Indígena Sororó.

Ter um espaço interditado às atividades necessárias à sobrevivência é preocupante em qualquer contexto, sobretudo entre os Suruí, que enfrentaram/enfrentam problemas que provocaram/provocam escassez de alimentos, como foi o caso do incêndio que atingiu a Área em 1996 (BELTRÃO, 1998a).

Além disso, o corpo jogado na Área representa a interrupção do ciclo de vida tal como o concebem os Suruí Aikewára. Os mortos devem ser enterrados e de forma ritual. Jogar o corpo, mesmo de um desconhecido, no mato ou na pista é coisa de kamará, não de Suruí. Da maneira como foi encontrado, o corpo, além de contaminar os animais, é um incômodo para os Suruí, pois o espírito dele vaga num território que não é o seu, ele é um intruso no universo Aikewára.

Como refere Tymykong:

aconteceu é, é ... essa tragédia foi assim, coisa ... é Luiza $^{77}$, o pessoal numa noite né, que Jurandir foi torar ${ }^{78}$ castanha, aí quando ele voltou encontrou os corpos do kamará lá na beira da pista né, aí, aí né, Jurandi veio falar com o povo aqui, e o pessoal foram ver, era um kamará que tava lá morto né, cortaram a cabeça dele, aí, numa noite a gente se uniu aqui e fizemo a interrupção

\footnotetext{
${ }^{77}$ A referência à Luiza de Nazaré Mastop-Lima veio em função da antropóloga costumeiramente, em períodos de campo, ter acompanhado os Suruí pelos castanhais.

${ }^{78}$ No sentido de cortar, como dizem os kamará, ou coletar castanha.
}

Espaço Ameríndio, Porto Alegre, v. 2, n. 2, p. 194-258, jul./dez. 2008. 
BELTRÃO, MASTOP-LIMA e MOREIRA - De vítimas a indiciados ...

da estrada né, porque eles tavam jogando lixo e cadáver, já quatro cadáver né Mairá ${ }^{79}$ ? Que eles já acharam lá, tão. jogando lixo velho lá também, aí, aí foi assim, aí começou, aí o pessoal, os homem tava tudo na beira da estrada, nós passamo duas noite que tavam né, com duas noite aconteceu esse negócio com esse homem, todos os caminhonero respeitou, só não ele que não respeitou (Entrevista com Suruí, 19/06/2003 - grifos nossos) ${ }^{80}$.

\section{O “norte" conquistado pela memória}

A memória Suruí Aikewára serve de guia, oferece rumo, direção aos membros da sociedade, é o lastro da cultura Aikewára. Ao referirem as situações sociais em que se verificam ameaças ao seu modo de vida e morte de seus membros, trazem à cena a degradação dos recursos ambientais que provocam profundas alterações na estrutura das relações sociais estabelecidas dentro da aldeia e na "rua", fora da aldeia ${ }^{81}$. A construção social de seu passado é uma forma de avaliar e elaborar as novas situações que são obrigados a enfrentar.

A importância da memória, especialmente de pessoas mais velhas e experientes entre os grupos indígenas é fato comprovado pela literatura antropológica. A memória, mesmo entre nós, é um fenômeno social e assim deve ser tratada. Ela é construída socialmente mesmo em seu aspecto individual, pois a memória individual depende de referenciais como por exemplo família, classe social, escola, religião, entre outros aspectos que podem ser considerados. Da mesma forma como se considera $o$ ato de conceber o mundo como uma característica inerente a toda a humanidade, também assim pode-se considerar o ato de lembrar. Lembrar, como quer Bosi, baseada em Halbwachs, "... não é reviver, mas refazer, reconstruir, repensar, com imagens e idéias de hoje, as experiências do passado" (BOSI, 1994, p. 55).

\footnotetext{
${ }^{79}$ Clara referência ao despejo de corpos na Área Indígena Sororó, eventos que se tornaram freqüentes após a ampliação e o asfaltamento da BR-153.

${ }^{80}$ Depoimento da representante apontada pela comunidade, via Mairá, para narrar na entrevista coletiva as ocorrências.

${ }^{81}$ Sobre as múltiplas faces aldeia/rua, consultar Mastop-Lima (2002).
}

Espaço Ameríndio, Porto Alegre, v. 2, n. 2, p. 194-258, jul./dez. 2008. 
BELTRÃO, MASTOP-LIMA e MOREIRA - De vítimas a indiciados ...

Marilena Chauí, ao apresentar o estudo de Bosi, mostra que a autora expõe como a sociedade capitalista oprime, despoja e bane a velhice, usando de:

... mecanismos institucionais visíveis (a burocracia da aposentadoria e dos asilos), por mecanismos psicológicos sutis e quase invisíveis (a tutelagem, a recusa do diálogo e da reciprocidade que forçam o velho a comportamentos repetitivos e monótonos, a tolerância de má-fé que na realidade é banimento e discriminação), por mecanismos técnicos (as próteses e a precariedade existencial daqueles que não podem adquiri-las), por mecanismos científicos (as 'pesquisas' que demonstram a incapacidade e a incompetência sociais do velho) (CHAUÍ, 1994, p. 18).

Ser velho na sociedade capitalista é, segundo o que mostra Marilena Chauí considerando o trabalho de Bosi, “... lutar para continuar sendo homem" (1994, p. 18). O fato de os velhos na sociedade não-indígena lutarem para continuar sendo homens, lembra a luta dos índios perante a sociedade nacional para ter sua identidade reconhecida. Os índios, assim como os velhos na sociedade não-indígena, são também oprimidos, despojados e banidos. Com a situação de contato, às sociedades indígenas coube servidão, solidão, fome e barbárie. Com os Suruí Aikewára não tem sido diferente.

A luta para ser índio, caracteriza-se por ser a luta para se mostrar gente, e gente diferente que precisa ser respeitada em suas particularidades étnicas. A luta dos Suruí Aikewára pode ser verificada quando se organizam em uma associação para reivindicar seus direitos ou quando se associam com outras etnias indígenas, como ocorre com o caso da Associação dos Povos Indígenas do Tocantins (APITO). Manter marcas étnicas, respeitar a tradição, aprender a narrar mitos e histórias de contato que dão significado ao espaço por eles ocupado é também uma forma de caracterizar a luta para ser reconhecido como gente, além de manter as fronteiras que os distinguem de membros da sociedade não-indígena e de membros dos demais grupos indígenas ${ }^{82}$.

\footnotetext{
82 Para uma detida análise sobre memória e identidade entre os Suruí Aikewára consultar Mastop-Lima (2002).
}

Espaço Ameríndio, Porto Alegre, v. 2, n. 2, p. 194-258, jul./dez. 2008. 
BELTRÃO, MASTOP-LIMA e MOREIRA - De vítimas a indiciados ...

A experiência vivida pelos Suruí na "rua", portanto para além da aldeia, é marcada pelo desrespeito. Fora da aldeia e de seu território eles protestam, mas acreditam que pouco ou nada podem fazer. Apesar de mais recentemente (final dos anos 90) terem encontrado apoio via Ministério Público Federal, sempre referido a partir do "Biratan" ou "Dotô Biratan"83. Na ausência de procuradores da República em Marabá, motivadas por razões de várias ordens, os Suruí se acostumaram a tratar com o Dr. Ubiratan Cazetta de forma mais permanente, daí a referência. Além do que, o primeiro Laudo elaborado em face da ampliação e asfaltamento da BR-153 foi entregue à comunidade pelo Procurador da República que, mesmo atuando em Belém, estava responsável àquela altura por Marabá, tanto que se deslocava de 15 em 15 dias para o município. Há familiaridade com os procuradores, desde a época da $\mathrm{Dr}^{\mathrm{a}}$ Neide Cardoso, passando por Dr. Sidney Pessoa Madruga, Dr. José Cardoso Lopes, Dr. José Nilso de Lírio, Dr. Zilmar Antonio Drumond e, mais recentemente, com o Dr. Osvaldo Sowek Júnior e $\mathrm{Dr}^{\mathrm{a}}$ Eloisa Helena Machado, que auxiliaram os Suruí Aikewára a pensar seus direitos, em relação aos brancos, e a exigir compensações, suas ações são um termômetro e um alerta ${ }^{84}$.

\section{Pluralismo jurídico, pouco plural}

No Estado do Pará, não é difícil encontrar conflitos jurídicos ou de outros tipos em terra indígena, como o observado recentemente (junho de 2003) entre os índios Gavião Parkatêjê e a Companhia Vale do Rio Doce (CVRD), resultando na obstrução da estrada de ferro ${ }^{85}$ através da qual o

\footnotetext{
${ }^{83}$ Referência coloquial ao Dr. Ubiratan Cazetta, Procurador da República em Belém, que por várias vezes ouviu e providenciou as demandas Suruí. A diferença entre "Biratan" e "Dr. Biratan" é feita em função dos presentes, pois a sensibilidade Aikewára compreende em parte a lógica da hierarquia do mundo dos brancos.

${ }^{84}$ Inúmeras são as solicitações feitas pelos Surú Aikewára feitas ao Ministério Público Federal, assim como são numerosos os documentos dos procuradores em favor dos indígenas.

${ }^{85}$ Este não foi o primeiro e por certo não será o último conflito entre índios e brancos, mas por ser recente torna-se referência. Os Gavião Parkatêjê também não são a única sociedade em litígio com a sociedade nacional, ficando apenas no sudeste do Pará tem-se: Assurini, Parakanã, Xikrín entre outros que integram a APITO. A exacerbação do conflito é tamanha que na área existem índios assentados, situação inimaginável há trinta anos. Para uma ampla visão da situação indígena no sul do Pará, mais especificamente na área de influência da Companhia Vale do Rio Doce, consultar Laraia e Santilli (1997).
}

Espaço Ameríndio, Porto Alegre, v. 2, n. 2, p. 194-258, jul./dez. 2008. 
BELTRÃO, MASTOP-LIMA e MOREIRA - De vítimas a indiciados ...

minério é transportado de Carajás/PA para São Luiz/MA. Não há como negar a existência de diferenças étnico-culturais e a convivência com as dissensões, quase sempre conflituosas, rapidamente intensificadas, a partir da década de 60, com o desenvolvimento do contato entre sociedades indígenas e sociedade nacional, face ao processo de expansão capitalista na região Amazônica, especialmente no sudeste do Pará.

No campo jurídico, esses conflitos se manifestam principalmente na resistência da sensibilidade jurídica dos índios no estado do Pará, constituída paralelamente ao sistema de racionalidade jurídico positivo; na noção positivada de justiça e o que é justiça dos diferentes pontos de vista local, observadas formas ritualísticas e procedimentais para alcançá-la; bem como na expressão pluralismo jurídico e nas pressões da sociedade nacional sobre os diferentes modos de ser.

Independente da importância do direito positivo para o estabelecimento do estado democrático de direito no Brasil, o mesmo não contempla as diferenças étnico-culturais existente no país, e, particularmente, no estado do Pará, pois, em suas premissas universais subjaz projeções de uma perspectiva homogeneizante, induzindo-se a imaginar que há no cenário nacional, mais homogeneidade do que realmente existe, ao converter diferentes visões de mundo em unidade conceitual. Negligenciando, portanto, o saber local. Admite-se a existência e os direitos de diferentes grupos, mas na prática o pluralismo não se faz presente.

O caso Divino Eterno suscita questões empíricas interessantes e difíceis de serem resolvidas, relativas ao pluralismo jurídico, tais como a atuação prática à adjudicação autêntica, e, ao reconhecimento social da sensibilidade jurídica dos Suruí Aikewára, vivendo estes em um contexto marcado pela dissensão crônica, impossível de ser equacionada em curto prazo e com tendência agudizante, especialmente porque o estado do Pará e a União não cumprem acordos previamente assinados. Acordos que, aliás, não precisariam vir a público se os preceitos constitucionais, mesmo com a marca de homogeneidade, fossem observados. 
BELTRÃO, MASTOP-LIMA e MOREIRA - De vítimas a indiciados ...

Para os antropólogos, estudiosos das diferenças culturais, é consenso que em toda sociedade existe um corpo de categorias culturais, ou códigos normativos instituídos socialmente que definem os direitos e deveres entre os homens, bem como os meios através dos quais os conflitos são dirimidos, reafirmando ou redefinindo tais categorias (CLASTRES, 1978).

Geertz (1998) concebe o direito como uma forma específica de imaginar a realidade, uma forma de ver o mundo semelhante à ciência, à religião, à arte ou ao senso comum. A especificidade do direito está no conjunto de práticas e/ou no instrumental empregado na administração das disputas e dos conflitos sociais que essa própria forma de ver o mundo impõe aos que a ela se subordinam. Nessa concepção,

... a dialética que parecia existir entre o fato cru e o julgamento ponderado, entre aquilo que simplesmente é, e aquilo que é correto, é, ... uma dialética entre a linguagem [sistema simbólico] de coerência coletiva, por mais vaga e incompleta que seja, e uma outra de conseqüência específica, por mais oportunista e improvisada que seja (GEERTZ, 1998, p. 276-277).

Para Geertz (1998), o direito não se realiza somente como um conjunto sistemático de leis, decretos, portarias, medidas provisórias, procedimentos formais e princípios abstratos. Consubstancia, também, o “... saber local; local não só com respeito ao lugar, à época, à categoria e variedade de seus temas, mas também com relação a sua nota característica" (GEERTZ, 1998, p. 324) ${ }^{86}$.

Nessa perspectiva, o caso Divino Eterno não pode ser reduzido a uma questão meramente técnica de transformar diferenças concretas em semelhanças abstratas ou simplesmente descobrir tipificações idênticas expressas em denominações distintas, envolvendo somente a relação entre o estabelecimento de normas e a representação de fatos, como se a questão fosse puramente terminológica e não ontológica. Pois se assim se procedesse, realizaria apenas um exercício de taxonomia jurídico-

\footnotetext{
${ }^{86}$ Para uma compreensão da lógica descrita por Geertz na sociedade ocidental, consultar Thompsom (1987 e 1998).
}

Espaço Ameríndio, Porto Alegre, v. 2, n. 2, p. 194-258, jul./dez. 2008. 
BELTRÃO, MASTOP-LIMA e MOREIRA - De vítimas a indiciados ...

institucional, sem alcançar o objetivo central do trabalho que é concentrar esforços na tentativa de desvendar a sensibilidade jurídica característica da organização social dos Suruí Aikewára, tendo como referência o conflito em que de vítimas se tornaram indiciados.

Conforme Portaria No 146/03, de 09/05/2003, da Delegacia de Polícia Federal em Marabá/PA, os Suruí Aikewára estão indiciados pela prática dos crimes de roubo qualificado e lesão corporal, por terem suas condutas emolduradas nos tipos penais pré-figurados, respectivamente, nos artigos 157, § $2^{\circ}$, I, e 129, ambos do Código Penal Brasileiro (CPB).

Enquanto o Boletim de Ocorrência n. ${ }^{\circ} 2003.000110$, de 17/03/2003, que serviu de base para a instauração do Inquérito Policial Federal, tipificou a conduta dos Suruí Aikewára como crime de roubo simples e tentativa de homicídio, previstas, respectivamente, nos artigos 157, caput e 124 c/c 14, II, todos do CPB.

Evidente que do ponto de vista jurídico-positivo, o detalhe, acima apontado, não constitui qualquer irregularidade, pois em direito penal o(s) indiciado(s) ou denunciado(s) não se defendem de capitulação penal e sim de fatos a ele(s) imputado(s). Mas é justamente aí que surge o problema. Os fatos são construídos conforme a visão social de mundo que os edificam. Portanto, antes de qualquer tipificação, ou propositura de uma ação penal, a contextualização cultural do caso Divino Eterno é indispensável a uma análise jurídica mais profunda, sob pena de se produzir somente uma explicação causal ou um julgamento moral do acontecimento. Afora, constituir-se em mais um julgamento de kamará contra os Suruí.

Indubitavelmente, a simplificação dos fatos, a sua redução às capacidades genéricas presentes nos códigos em vigor é inevitável e até necessária ao desenvolvimento de um processo judicial. Todavia, sempre há o risco da exagerada simplificação, podendo tornar temerosa à avaliação dos fatos, pois os mesmos estão destituídos da complexidade de seu contexto cultural. E o contexto das ocorrências deve ser necessariamente levado em consideração para que a justiça possa ser feita. 
BELTRÃO, MASTOP-LIMA e MOREIRA - De vítimas a indiciados ...

Ademais, a prática jurídica, particularmente na esfera penal, demonstra que nos tribunais o que se busca construir, certamente não é a suposta "verdade real", conforme prevê o direito positivo, mas as visões de mundo dos operadores do direito, pois, os fatos não vêm ao mundo espontaneamente, eles são construídos socialmente por uma série de elementos jurídicos e extra-jurídicos.

Assim, em um processo judicial, observando apenas parte desse contexto cultural, pode-se, perfeitamente, construir um fato, a partir das concepções da sociedade nacional, tomando-o como verdadeiro, mas o mesmo é injusto pois ratifica, simultaneamente, o veredicto e a visão social de mundo dominante. Se assim se procede o mundo vira de ponta-cabeça.

Nessas dissensões que envolvem o campo do pluralismo jurídico, Geertz (1998) indica um importante componente ideológico obscurecido pela natureza jurídica do processo. Pois, o processo judicial é

... uma forma de conseguir que nossas concepções do mundo e nossos veredictos se ratifiquem mutuamente, ou utilizando uma expressão menos cotidiana, fazer com que essas concepções e esses veredictos sejam respectivamente o lado abstrato e o lado prático da mesma razão constitutiva (GEERTZ, 1998, p. 271).

Pensando a partir de Geertz (1998), se a ação penal proposta contra os Suruí Aikewára, pela queixa oferecida por Divino Eterno e Juliana Pagani, possivelmente, assumirá diferentes configurações factuais, adstritas ao processo de edição da realidade produzida. Geertz (1998) destaca que a configuração factual assumida por um acontecimento, realiza-se como um fenômeno que está na base de toda cultura, ou seja, pelo processo de representação.

A descrição de um fato de tal forma que possibilite aos advogados defendê-lo, aos juízes ouvi-lo, e aos jurados solucioná-los, nada mais é que uma representação: como qualquer comércio, ciência, culto, ou arte, o direito, que tem um pouco de todos eles, apresenta um mundo no qual suas próprias descrições fazem sentido (GEERTZ, 1998, p. 259). 
BELTRÃO, MASTOP-LIMA e MOREIRA - De vítimas a indiciados ...

Assim, Geertz (1998) conclui que o direito é a parte jurídica do mundo expresso em uma forma específica de imaginar a realidade. Pois, ao se tratar juridicamente um acontecimento como, por exemplo, o caso Divino Eterno,

[t]rata-se, basicamente, não do que aconteceu, e sim do que acontece aos olhos do direito; e se o direito difere, de um lugar ao outro, de uma época a outra, então o que seus olhos vêem também se modifica (GEERTZ, 1998, p. 259).

Usando das observações do autor supra mencionado, o Laudo, ora apresentado, traz a versão dos Suruí Aikewára, aqueles que por não pautarem sua conduta pela lógica da sociedade nacional, deixaram de apresentar a queixa, tornando-se duplamente vitimados, pela ameaça no 17 de março de 2003 e pela denúncia oferecida em São Geraldo do Araguaia que origina seu indiciamento.

Qualificar a conduta praticada pelos Suruí Aikewára como crime de roubo qualificado e lesão corporal, é o meio pelo qual a Polícia Federal traduz a linguagem da imaginação para a linguagem da decisão jurídica, criando assim um sentido de justiça determinado ao se instaurar o inquérito policial. Ou seja, significa representar uma situação concreta em uma linguagem de coerência geral com conseqüências específicas.

Assim, a imputação criminal e a instauração do procedimento inquisitorial, não se reduzem apenas a técnicas de organizar a evidência e apurar o fato, dito criminoso, pois descreve uma série de eventos no qual encontra-se enraizada uma concepção geral do mundo e a representação verdadeira do acontecimento, mas para a justiça realizar-se, torna-se necessário considerar a versão Aikewára.

Conforme acentua Geertz (1998), o pluralismo jurídico se constitui elemento central no cenário moderno - e o Brasil integra este cenário - e não como anomalia temporária. Portanto, nessa dissensão, a visão instrumental do direito, que ante esse caso específico opere meios para tornar realidade valores sociais estabelecidos em outro contexto, não é 
BELTRÃO, MASTOP-LIMA e MOREIRA - De vítimas a indiciados ...

válida, embora possa ser legítima e legal. Assim, faz-se necessário pensar o direito em uma dimensão hermenêutica,

... como uma forma de dar um sentido específico, a coisas específicas em lugares específicos (coisas que acontecem ou deixam de acontecer, coisas que poderiam acontecer), de modo que esses instrumentos nobres, sinistros ou meramente práticos possam adotar formas específicas e ter um impacto específico (GEERTZ, 1998, p. 351).

Caso contrário poder-se-á produzir, em respostas a essa dissensão, a esterilização dos fatos, pervertendo tanto a prática do direito quanto as reflexões possam incidir sobre ele. Faz-se imperioso considerar a sensibilidade jurídica dos indígenas indiciados no Inquérito.

\section{Suruí Aikewára, um exemplo de sensibilidade jurídica}

No caso Divino Eterno, o sentido de justiça só se manifestará se o fato for considerado a partir das bases culturais Suruí Aikewára. Pois, a sensibilidade jurídica varia nos meios que utilizam para apresentar eventos judicialmente, nos símbolos que empregam, nas distinções que estabelecem e no poder que as mesmas exercem sobre os processos da vida social, frente a outras formas de pensar, agir e sentir.

Para Geertz (1998), a sensibilidade jurídica é como um “... complexo de caracterizações e suposições, estórias sobre ocorrências reais, apresentadas através de imagens relacionadas a princípios abstratos ..." (GEERTZ, 1998, p. 325).

Nesse caso, a sensibilidade jurídica se apresenta de forma bem definida entre os Suruí Aikewára. Ao transpor o "entupidimento" da estrada, situada em terra Suruí, com um caminhão em alta velocidade, Divino Eterno praticou pelo menos três erros fundamentais, invadiu o território indígena, colocou em risco a vida de crianças e desrespeitou uma determinação coletiva, produzindo a um só tempo três eventos perturbadores da ordem Suruí que deveriam, portanto, ser corrigidos. 
BELTRÃO, MASTOP-LIMA e MOREIRA - De vítimas a indiciados ...

Conforme se observou na decisão de "entupidinir" a rodovia, no mundo Suruí o direito não é uma mera expressão dos comandos do cacique. Ao contrário, os comandos de Mairá, bem como as ações de qualquer outro índio, se "condizentes" com a vontade coletiva, realizam-se como uma expressão do direito.

Nesse contexto, a questão central não era se Divino Eterno tinha direito a um julgamento onde the fosse garantido os princípios constitucionais da ampla defesa, do contraditório e do devido processo legal. Para os Suruí, esses detalhes eram irrelevantes naquele momento, pois não se aplicam ao seu contexto cultural. Assim como não se aplicava ao contexto ir dar queixa de Divino Eterno na Delegacia de Polícia de São Geraldo do Araguaia, pois esta instância, embora conhecida, não faz parte do quotidiano da sociedade.

Todos os índios que entrevistamos na aldeia foram unânimes em considerar execrável a conduta praticada por Divino Eterno. Todos acreditavam, em seus próprios termos, que as mães que o submeteram à paxiba agiram condizentemente com a sensibilidade coletiva. Portanto, em outro contexto, não cabe saber se essas mães agiram "certo" ou "errado". Pois, a questão é "... dadas as crenças, como devemos agir; ou dados nossos atos, em que devemos acreditar" (GEERTZ, 1998, p. 270). Acreditase, portanto que os Suruí Aikewára estavam "cumprindo" a lei social, corrigindo o infrator. Inclusive, porque as autoridades não se faziam presentes na ocasião.

A conduta, dita criminosa, praticada pelos Suruí não está associada à noção positiva de lei. Todavia, o "dever ser", conceito que embora se apresente com pouca nitidez, revela uma conexão interna e inseparável entre o "condizente e o não condizente" com a realidade local; entre "um comportamento correto" e o "incorreto de um comportamento"; entre o "dever e o respeito", correspondendo, de uma maneira geral, ao conceito de lei, decreto, portaria, regras e regulamentos, relacionado à prática de atos judiciais, tais como proferir uma sentença e imputar uma pena. Ou seja, uma compreensão do "dever ser" e do "que realmente é". 
BELTRÃO, MASTOP-LIMA e MOREIRA - De vítimas a indiciados ...

E essa identificação do "condizente e não condizente", "correto e incorreto", "dever e respeito" permeia a sensibilidade jurídica Suruí não só de uma forma abstrata, mas concretamente, como nos processos de deliberação e nos procedimentos. Assim, tipificação Suruí não envolve somente a conexão de uma situação empírica a um princípio jurídico; esses dois elementos surgem juntos. O dever ser, destarte, não se realiza como execução de uma ordem universal ou absoluta, mas como manifestação clara de um acordo coletivo.

Para os Suruí Aikewára, quando Divino Eterno ultrapassou a barreira que provocava a obstrução da estrada, ultrapassou também os limites da cultura. A barreira é um código de kamará, utilizado pelos índios para comunicar aos kamará uma obstrução. Ao verificar que o caminhoneiro podia não estar vendo a barreira, os guardiões Suruí acionaram outro código kamará, acenderam lanterna e sinalizaram alertando para o problema. Divino Eterno conhece ambos os códigos, afora o fato de ter sido alertado verbalmente em Some Home sobre os problemas que estavam acontecendo. Ao desrespeitar os códigos de sua própria cultura intencionalmente (dada suas declarações) e invadir as terras Suruí, acionou a justiça Aikewára.

Logo, passar a paxiba em Divino Eterno revela uma representação do real, associada a um conjunto de imperativos a serem respondidos, a uma visão de mundo onde a vontade coletiva se encontrou. O dever ser, nesse caso, não é neutro, metafísico e inerte à espera da movimentação dos operadores do direito legitimados para tal. Ao contrário, realiza-se como ativo, profundamente envolto da moralidade quotidiana e práticas socialmente estabelecidas, associadas ao significado de direito, que retrata como as coisas geralmente são, revelando a conexão de um sentido geral de como as coisas se relacionam, compondo a sensibilidade jurídica Suruí Aikewára. Ressalte-se que nenhuma autoridade kamará, apesar dos chamados, via rádio, se fazia presente.

A importância da sanção aplicada a Divino está na tarefa prática de buscar a harmonia social e a compostura individual, evitando, assim, a dissonância social. Ou seja, nesse contexto cultural, o que importa afinal é 
BELTRÃO, MASTOP-LIMA e MOREIRA - De vítimas a indiciados ...

que essa unidade mental se manifesta não tanto na sanção em si, que é apenas desdobramento do ato praticado por Divino Eterno, mas nos processos sociais nos quais é gerada.

Urge, não esquecer, que ao longo dos tempos, constrangidos pelos abusos, os Suruí foram obrigados a defender-se, aprenderam que na ausência das autoridades constituídas, quaisquer que fossem as razões, teriam que agir. E agiram, detiveram o infrator e aguardaram os agentes tutelares, mas a suposta "boa fé" dos agentes, que mesmo exercendo o papel de operadores do direito, não estão aptos a interpretar a lei, não ofereceram queixa policial da ameaça sofrida pelos indígenas. Além de, na tentativa de dirimir o conflito, de solucionar o impasse liberaram o caminhoneiro sem aguardar os agentes da Polícia Federal, estes sim autorizados e com prática de supervisionar a observância da lei em área indígena.

A essência da sensibilidade jurídica Suruí não está na aplicação dos princípios processuais inerentes ao direito positivo, nem na apuração dos fatos e sua adjudicação, mas, essencialmente, no juízo de "adequação e inadequação" à situação fática aos valores coletivos do local.

Assim, o julgamento da transgressão praticada por Divino Eterno flui segundo a visão de mundo Aikewára, onde o respeito às normas e aos outros são fundamentais para a manutenção da ordem, independente do que essa ordem seja realmente. O fato é que existem regras a serem obedecidas. As noções de "adequado e inadequado", "correto e incorreto", "respeito e dever" fazem parte daquilo que a ordem significa, costurando pontos de vista da comunidade, traduzidos em expressões como: “... mas ele foi culpado" ... "veio com falta de respeito". Ou sob forma de perguntas: "por que ele não teve paciência aí? Por que não pediu também?"87.

Várias vezes, em tom de reprovação os interlocutores diziam: "Suruí é assim [não desrespeita], né? Não é igual kamará doido não. Se vê uma barreira para ... tem que pará. É do trânsito! Alguns indígenas sabem dirigir e possuem carteira nacional de habilitação, enquanto motoristas procuram respeitar as normas para não serem chamados atenção.

\footnotetext{
${ }^{87}$ Expressões de descontentamento ouvidas durante a estada da equipe, na Aldeia Sororó em junho de 2003.
} 
BELTRÃO, MASTOP-LIMA e MOREIRA - De vítimas a indiciados ...

E arrematam suas observações dizendo: "a gente tem maior respeito quando tem polícia federal, ou polícia ... Mata cachorro lá, a gente pará ${ }^{88}$. A gente não passa assim com tudo não ... ninguém passa assim na tora não" (Entrevista com Suruí (Mahú), 20/06/2003).

No que foi complementado por Tymykong: "não, os índio não errou. Kamará foi que errou. Pois é, ... ele foi errado, agora ele quer ser direito [fazer denúncia]" (Entrevista com Suruí, 19/06/2003).

Os Suruí constróem representações dos eventos, de forma prática, moral e jurídica, situando os fatos em estruturas mais amplas de significações, organizando suas ações em seus termos. Nesse caso, representação da culpa imputada a Divino Eterno foi definida em termos de ameaça à vida de jovens indígenas, invasão de território e desrespeito a determinação coletiva. Embora pareçam estranhas, essas representações revelam uma sensibilidade jurídica específica ${ }^{89}$. Durante as reuniões ocorridas em face da elaboração do Laudo, Terí, a mãe dos jovens ameaçados perguntou: "qual a mãe que não protege os filhos? Ao que alguém acresceu: "até bicho protege, nós [os Aikewára] protege os nossos!"

E Terí prossegue esclarecendo:

então eu acho que é ... chegou um ponto da gente conversar direito que essa terra aqui é nossa quando os branco vieram descobrir o que é que é índio aqui. Então porque que nós não tem direito de fazer as coisa nessa terra aqui, que nós somo tudo índio. Então eu sou a ... eu sou também daqui. Então eu acho que ele ... ele tinha que ter respeitado a nossa barreira. Não atravessado, pulado a .... a ... os pau que nós é ... os menino tinha botado aqui né. $E$ eu também, eu fiquei na barreira até o dia amanhecer porque meu filho tão junto né. Esse aqui, esse aqui olha, ele quase mata esse menino aqui ó. E eu dou a minha vida pelos meus filhos né. Eu só gosto dos meus filho né. Então quando eu soube que ... os pessoal me contaram a ... "titia Terí corre que teu menino ia morreno". Aí eu fiquei perturbada nessa hora, porque se a ... acontecer alguma coisa com a ... a ... rumo dos meus

\footnotetext{
${ }^{88}$ Cachorro é uma referência genérica ao atropelamento de animais na estrada. É também uma forma de dizer que atendem aos códigos dos kamará quando estão "na rua."

${ }^{89}$ Para melhor compreender a cultura como um sistema simbólico consultar Geertz (1998). E para conhecer “como opera a cultura”, inclusive, entre os Suruí Aikewára, consultar Laraia (1986a).
}

Espaço Ameríndio, Porto Alegre, v. 2, n. 2, p. 194-258, jul./dez. 2008. 
BELTRÃO, MASTOP-LIMA e MOREIRA - De vítimas a indiciados ...

filho a ... aí eu ... sou capaz até de perder a minha vida. Eu sou desse jeito. Então foi por isso que aconteceu né, porque ele desrespeitou a barreira e aí ele quis dá um de bom pra atravessar né. Porque os camioneiro já tinha avisado ele que não era pra atravessar porque os índio já tinha feito a barreira e ele atravessou. Mandou a mulher deitar no carro pra ele poder atravessar né. Foi assim que aconteceu. E agora fica contano uma coisa e outra pros outro. Não conta uma coisa certa. Ele não conta dos erro que ele fez né. Ele não conta (Entrevista com Suruí, 20/06/2003 - grifos nossos).

Parte da visão de mundo Suruí Aikewára está retratada no trabalho $O$ tempo antigo entre os Suruí/Aikewára: um estudo sobre mito e identidade étnica da antropóloga Luiza de Nazaré Mastop-Lima (2002), que revela uma organização social fundada na noção de dever e respeito à dignidade da pessoa e aos valores coletivos, em um mundo de apenas uma ordem dos seres, que é ao mesmo tempo natural, moral, material, espiritual e jurídica. Portanto, as normas não devem ser absorvidas pela subordinação a um modelo compreensível de vida e pensamento.

Nesse caso, sugere-se que o Inquérito Policial deve ser arquivado para evitar que o direito positivo atue subordinando a sensibilidade jurídica Suruí Aikewára. Pois,

[o] direito, com seu poder de colocar acontecimentos específicos - um compromisso aqui, uma injúria acolá em uma moldura geral de uma maneira tal, que as normas que regulam um gerenciamento adequado $\mathrm{e}$ probo desses acontecimentos pareçam surgir naturalmente dos elementos essenciais de seu caráter, é um pouco mais que um reflexo da sabedoria herdada, ou uma técnica para resolução de conflitos. Com razão ele atrai para si o mesmo tipo de paixão que aqueles outros procriadores de significados e propositores do mundo - a religião, a ideologia, a ciência, a moral e o senso comum - atraem (GEERTZ, 1998, p. 349).

Assim, as paixões que são intensas e inevitáveis não devem poluir o Inquérito, porque o que está, presumidamente, em questão é uma 
BELTRÃO, MASTOP-LIMA e MOREIRA - De vítimas a indiciados ...

concepção do direito que de "forma correta" possa apurar os fatos e instruí-los.

Nessa dissensão a questão fundamental não é se a sensibilidade jurídica dos Suruí Aikewára pode ou não ser concebida como direito, o que importa é reconhecer o seu poder imaginativo, construtivo ou interpretativo que tem sua força sustentada nos recursos coletivos da cultura local. Como informa Tibakú, pai dos Suruí ameaçados, enfatizando a ação coletiva:

tanto faz os daqui como os de lá. É isso que nós fizemo. Mas aí ... então se for pra chamar só os três que foi na lista ... que ele botou na lista, então era ...então eu falei pro Mairá "não Mairá sendo assim então não adianta você manda esses três índio, pra ir só os três pra dá depoimento tem que ser nós tudinho porque nós tudo tava no meio", né. Não, era nós tudo não era dois, três pessoa que tava não. Era nós tudo. E porque que o homem botou só o nome dos três, que era culpado, que ... a Terí, o Machú [Umassú] e o Alex. O Alex, coitado, não tava lá, ele tava cá na frente também (Entrevista com Suruí, 20/06/2003 - grifos nossos).

Ademais, deve-se considerar, ainda, que a sensibilidade jurídica Aikewára é permeável, tanto que os Suruí apesar de não terem perdido seus códigos, terminaram adaptando aos novos tempos, quando o contato é intenso. A comprovação do que se afirma está na tentativa de dialogar com o "mundo dos brancos", ainda que parcialmente, os índios articulam o saber local e o processo global de expansão capitalista, fundada na organização social da aldeia, sob a vigilância de moradores, adaptada às circunstâncias e expressa através de símbolos também locais. Portanto, as mudanças decorrentes do processo de expansão capitalista não transformaram tudo tão absolutamente quanto se pensa, sobretudo as formas de sensibilidade jurídica. No Brasil, o direito positivo se tornou hegemônico e até causídico. Porém, não perdeu seu relacionamento com a vida local. 
BELTRÃO, MASTOP-LIMA e MOREIRA - De vítimas a indiciados ...

\section{Com a cabeça no lugar}

Usando do "direito dos brancos" tenta-se mostrar a apreensão dos códigos brasileiros e a sensibilidade jurídica dos Aikewára.

Se a situação tivesse tido lugar em nossa sociedade, e trabalhando por suposição tivéssemos nossa terra ou nossa casa invadida por alguém que, ignorando todas as normas, sem nossa licença ameaçasse nossos filhos, que faríamos nós? Especialmente considerando que, apesar de chamadas, as autoridades não chegaram a tempo ou não se fizeram presentes. É necessário não esquecer que ao encontrarem o corpo, os Suruí, por rádio, solicitaram a presença da FUNAI, ao deterem Divino Eterno, o contiveram e aguardaram a chegada dos agentes tutelares.

Por certo sem consultar qualquer pessoa tentaríamos agir, pois na ausência das autoridades constituídas para nos oferecer proteção, fazemos as suas vezes, fato que nos é facultado, pois estamos resguardando vidas e patrimônio. Aliás, abrindo os jornais, os exemplos se multiplicam. Ninguém parece estranhar que alguém reaja a uma agressão. Embora que, na crítica situação de violência, a ordem mais sensata é não reagir.

Continuando a examinar o caso, usando da lógica do direito brasileiro, argumentaríamos que ameaçados e na ausência de operadores do direito, os Suruí agiram sob violenta emoção protegendo seus filhos de mais um massacre, entre os muitos perpetrados contra eles. Justo quando estão unicamente reivindicando o que lhes é devido.

\section{Referências bibliográficas}

AZEVEDO, Francisco Ferreira dos Santos. Verbete Julgamento. In: Dicionário Analógico da Língua Portuguesa (idéias afins). Brasília: Coordenada/Thesaurus, 1983. p. 224-226..

BELTRÃO, Jane Felipe. Laudo Antropológico - Área Indígena Sororó a propósito da BR-153. Campinas, 1998a. Mimeo.

Laudo Antropológico - Reserva Indígena Mãe Maria a propósito da BR-222. Campinas, 1998b. Mimeo. 
BELTRÃO, MASTOP-LIMA e MOREIRA - De vítimas a indiciados ...

Haraxare Krokti Ronore Konxarti e a vilgilância do território Gavião Parkatêjê - Laudo Antropológico. Belém, 2001. Mimeo.

. Haraxare Krokti Ronore Konxarti e a vigilância do território Gavião Parkatêjê. Revista Humanitas, Belém, v. 8, n. 1, p. 101-111, 2002a.

.Laudos \& Ética, por uma Antropologia em ação. In: CABRAL, Ana Suelly A. C.; RODRIGUES, Aryon Dall'Igna. Atas do I Encontro Internacional do grupo de Trabalho Sobre Línguas Indígenas da ANPOLL. Belém: EdUFPA, 2002. p. 384-392.

BOSI, Ecléa. Memória e Sociedade: lembrança de velhos. São Paulo: Cia. das Letras, 1994.

CHAUÍ, Marilena. Os trabalhos da memória. In: BOSI, Ecléa. Memória e Sociedade: lembrança de velhos. São Paulo: Cia. das Letras, 1994. p. xvii - xxxii.

CLASTRES, Pierre. A Sociedade contra o Estado. Rio de Janeiro: Francisco Alves, 1978.

CUNHA, Antônio Geraldo. Dicionário histórico das palavras portuguesas de origem Tupi. São Paulo: Melhoramentos/EdUSP, 1989.

EMMI, Marília Ferreira et al. O Polígono Castanheiro do Tocantins: espaço contestado de oligarquias decadentes. Pará Agrário, Belém, n.. 2, p. 12-21, jan./jun. 1987.

FERNÁNDEZ O., Marcelo. La ley del Ayllu: Práctica de jach'a justicia y jisk’a justicia (Justicia Mayor e Justicia Menor) en comunidades aymaras. La Paz-Bolivia: Programa de Investigación Estratégica en Bolivia, 2000.

FERREIRA, Aurélio Buarque de Holanda. Verbete Laudo. In: Novo Dicionário da Língua Portuguesa. Rio de Janeiro: Nova Fronteira, 1975. p. 823.

FREIRE, Paulo. Educação como prática da liberdade. Rio de Janeiro: Paz e Terra, 1975a.

. Extensão ou comunicação. Rio de Janeiro: Paz e Terra, $1975 b$.

. Pedagogia do Oprimido. Rio de Janeiro: Paz e Terra, 1975c.

GEERTZ, Clifford. Interpretação de Culturas. Rio de Janeiro: Zahar, 1978.

Vozes, 1998.

O Saber Local. Novos ensaios em Antropologia interpretativa. Petrópolis:

. Nova luz sobre a Antropologia. Rio de Janeiro: Jorge Zahar Editor, 2001.

Espaço Ameríndio, Porto Alegre, v. 2, n. 2, p. 194-258, jul./dez. 2008. 
BELTRÃO, MASTOP-LIMA e MOREIRA - De vítimas a indiciados ...

HOMMA, Alfredo Kingo Oyama et al. Razões de Risco e Rentabilidade na Destruição de Recursos Florestais: o Caso dos Castanhais em Lotes de Colonos no Sul do Pará. Revista de Economia do Nordeste, Fortaleza. v. 27, n. 3, p. 515-535, 1996.

KITAMURA, Paulo Choji; MÜLLER, Carlos Hans. Castanhais nativos de Marabá-Pa: fatores de depredação e bases para a sua preservação. Belém: EMBRAPA-CPATU, 1984.

LARAIA, Roque de Barros. Cultura, um conceito antropológico. Rio de Janeiro: Jorge Zahar Editor, 1986a.

Tupi: índios do Brasil atual. São Paulo: EdUSP, 1986b.

LARAIA, Roque de Barros; DaMATTA, Roberto. Índios e castanheiros: a emprêsa extrativa e os índios no médio Tocantins. São Paulo: Difel, 1967.

LARAIA, Roque de Barros; SANTILLI, Márcio Brando. Sugestões para o Gerenciamento Estratégico das Relações entre a CVRD e os Índios da área de Influência do Projeto Ferro-Carajás. Brasília: Instituto Socioambiental, 1997. Mimeo.

LÉVI-STRAUSS, Claude. Raça e História. In: COMAS, Juan et al. Raça e Ciência I. São Paulo: Perspectiva, 1970. p. 231-270.

MAGALHÃES, Sônia Barbosa. Tempo e trajetórias: reflexões sobre representações camponesas. In: HÉBETTE, Jean; MAGALHÃES, Sônia Barbosa; MANESCKY, Maria Cristina (Org.). No mar, nos rios e na fronteira: faces do campesinato no Pará. Belém: EdUFPA, 2002. p. 235-274.

MASTOP-LIMA, Luiza de Nazaré. O tempo antigo entre os Suruí/Aikewára: um estudo sobre mito e identidade étnica. 2002. 140 f. Dissertação (Mestrado em Antropologia) UFPA, [2002].

MOREIRA, Manuel. La cultura Jurídica Guarani: Aproximacion Etnografica a la Justicia Mbya-Guarani. Argentina: Antropofagia, 2005.

RICARDO, Carlos Alberto. Povos Indígenas do Brasil 8: sudeste do Pará (Tocantins). São Paulo: CEDI, 1985.

SYDENSTRICKER NETO, J. M. Apontamentos para uma reflexão: população e meio ambiente no contexto amazônico. In: Núcleo de Estudos da População Ambiente e Sociedade: possibilidades e perspectivas de pesquisa. Campinas: UNICAMP, 1992. p. 126152. 
BELTRÃO, MASTOP-LIMA e MOREIRA - De vítimas a indiciados ...

THOMPSOM, Edward P. Senhores e Caçadores: a origem da lei negra. Rio de Janeiro: Paz e Terra, 1987.

. Costumes em comum: estudos sobre cultura popular tradicional. São Paulo: Companhia das Letras, 1998.

VELHO, Otávio Guilherme. Frentes de Expansão e estrutura Agrária: estudo do processo de penetração numa área da Transamazônica. Rio de Janeiro: Zahar, 1972.

\section{Documentos}

Boletim de Ocorrência Policial Nº 2003.000110 - São Geraldo do Araguaia/Pará.

Inquérito 146/03 DPF. B/MBA/PA - Marabá - Pará.

Processo $N^{\circ}$ 010990/03/UFPA - Belém - Pará.

Espaço Ameríndio, Porto Alegre, v. 2, n. 2, p. 194-258, jul./dez. 2008. 
BELTRÃO, MASTOP-LIMA e MOREIRA - De vítimas a indiciados ...

ANEXO 1

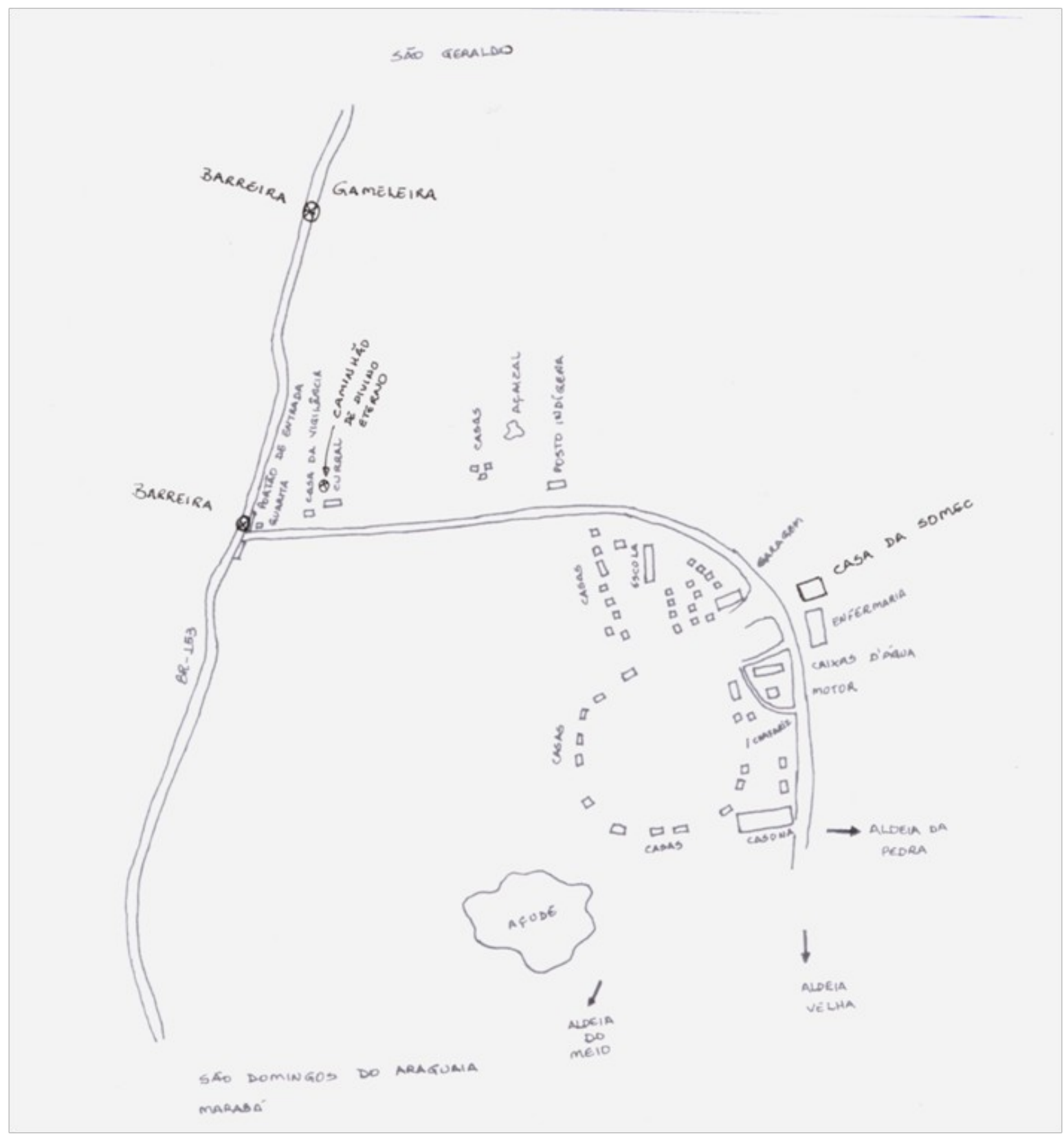

Ilustração 1

Espaço Ameríndio, Porto Alegre, v. 2, n. 2, p. 194-258, jul./dez. 2008. 